\title{
Measuring the digital divide at regional level. A spatial analysis of the inequalities in digital development of households and individuals in Europe
}

Lucendo-Monedero, A. L., Ruiz-Rodríguez, F., \& González-Relaño, R. Universidad de Sevilla, c/Maria de Padilla s/n, 41004, Sevilla, Spain.

Post-print version. Article published in:Telematics and Informatics, 41, August 2019, 197-217. https://doi.org/10.1016/j.tele.2019.05.002

\begin{abstract}
The aim of this paper is to identify the spatial inequalities in digital development (digital divide, DD) of households and individuals in Europe at regional level. Digital development is understood as the level of access to and use of Information and Communication Technologies (ICTs) in households and by individuals. This study has been undertaken using the following methodology: 1) factor analysis to identify the key variables of use of and access to ICTs in households and by individuals in European regions on the basis of data provided by Eurostat; 2) construction of a synthetic index, the household and individual digital development index (HIDDI) on the basis of identified factors; 3 ) analysis of the spatial autocorrelation of digital development to identify, delimit and quantify spatial patterns and clusters in European regions.
\end{abstract}

The results of this study lead to the conclusion that the digital development of households and individuals in European regions is founded on broadband Internet access. In this context, the level of digital development and the DD of European regions is based on households and individuals' daily use of e-commerce, e-banking and e-government services. However, the use of social networks in households with broadband shows less DD in Europe. The values obtained by using the HIDDI for each European region reveal that the maximum DD between these is $37 \%$, with the spatial autocorrelation analysis identifying a NW-SE pattern in Europe. Thus, a region's level of digital development is directly related to that of its neighbours; and geographical proximity/vicinity is an element to take into account when analysing the disparities of the DD.

Keywords: ICTs, NUTs 2 region, complex index, regional spatial pattern, spatial clusters.

\section{Highlights}

- The digital development of households/individuals in European regions is based on broadband Internet access.

- Households'/individuals' daily use of e-commerce, e-banking and e-government services establishes the level of digital development of European regions.

- The maximum DD between European regions is $37 \%$ of households/individuals, according to the HIDDI values.

- There is less DD between European regions in the use of social networks in households with broadband.

- The spatial autocorrelation analysis shows a NW-SE spatial pattern of DD among European regions. 


\section{Introduction.}

Digital development is understood as a process by means of which all the households and individuals in a society have access to Information and Communication Technologies (ICTs) and can use them for a wide range of basic public and private services, and also to communicate, interact and relate to each other and their governments. ICTs refer to the set of tools, usually of an electronic nature, used for the collection, storage, processing, dissemination and transmission of information. This set includes both physical devices (computer equipment, telecommunication networks, terminals, handsets, etc.) and the software or computer applications that run on these devices (INE, 2017). ICTs are a vector of social development and transformation (Sujarwoto and Tampubolon, 2016) as they improve citizens' access to basic services (Falch and Henten, 2017) and create new employment opportunities (Van Deursen and Van Dijk, 2013). Thus, several studies have shown (Barzilai-Nahon, 2006; Van Dijk, 2006, Vu, 2011) that the mere provision of ICT infrastructures does not enable the social inequalities existing in the global information society to be redressed (Helsper, 2012; Witte and Mannon, 2010) and thereby achieve sufficient digital development.

The inequalities in digital development are generically known as the digital divide (DD). The OECD (2001) defines DD as the gap between individuals, households, businesses and geographical areas at different socio-economic levels with regard to both their opportunities to access ICTs and their use of the Internet for a wide variety of activities (Van Deursen, et al., 2015; Alizadeh e Farid, 2017; Gonçalves et al., 2018; Jordá-Borrell et al., 2018). Within this context, numerous studies in the last decade have addressed the need to detect measure and understand the differences between a society having accessibility and/or its use of computers and the Internet (Yu, 2006; World Economic Forum, 2017).

From the perspective of a geographical analysis of the DD (geographical areas), the main indicators and indices created by different institutions to measure digital development do not reflect the complexity of this concept and have usually been applied at country level (Ruiz-Rodríguez et al.., 2018). Meanwhile, the study for other territorial levels, such as rural/urban areas is undertaken from the perspective of the digital inclusion of the rural population in view of the lack of access to infrastructures and/or individual ICT skills (Freeman et al, 2016; Salemink et al., 2017). Choosing the country level for geographical analyses of the DD may therefore conceal intra-national differences in access to and use of ICTs (Pick and Nishida, 2015) as states have large socio-economic disparities at regional level (Beugelsdijk et al., 2017 and 2018; lammarino et al., 2018; Charron et al., 2015). Hence, it is with good reason that the territorial cohesion policies in Europe are fundamentally designed and managed from and for regional political and administrative levels (European Commission, 2010; Asheim, 2018).

Moreover, the scientific literature on DD has focused on the identification of the socioeconomic and institutional factors that explain the different levels of digital development of countries/ rural-urban areas (Salemink et al., 2017). Meanwhile, the geographical distance between areas has been less studied as an element of diffusion of ICTs, although some authors have already shown that geographical proximity may exert an influence on the diffusion and scale of digital development and, consequently, on differences in DD (Corrocher and Ordanini, 2002). 
Consequently, a shortfall of studies that contribute to measuring and explaining the DD between European regions at household and individual level can be detected. There are still questions to be resolved: 1) What is the magnitude of the DD between European regions? 2) What types of ICTs define this digital divide? 3) Is there a spatial pattern of regional DD? Hence, the main objective of this paper is to identify the spatial inequalities in digital development of households and individuals at regional level in Europe. This objective entails: i) identifying the key variables that define the underlying structure of the digital development of households and individuals in European regions on the basis of data provided by Eurostat; ii) constructing a synthetic index to measure current achievements in digital development by European regions and, moreover, the DD between them; and iii) identifying the spatial patterns and clusters of European regions according to the level of digital development of households and individuals on the basis of the synthetic index in order to show the DD between them.

This paper first addresses the theoretical background of the DD of households and individuals at regional level in Europe. Second, there is a description of the methodology used to measure both the digital development of European regions and the DD existing between them and the resulting spatial pattern. In the following section, the results of the analysis are provided: the dimensions of digital development, the ranking of the level of digital development of European regions and the spatial inequalities between regions in terms of digital development. Finally, there is a discussion of the results obtained, conclusions are drawn, and there is an evaluation of their contribution to the scientific literature and to public policies for ICTs and for reducing regional inequalities.

\section{Theoretical background}

The first scientific studies on the DD primarily focused on examining the conditions of citizens' access to information (Riggins and Dewan, 2005; Kraemer et al., 2005). The DD was initially understood in a binary fashion and was restricted to distinguishing between having and not having access to ICTs (first level of analysis of the DD, according to Scheeders et al., 2017; Cruz-Jesus et al., 2012; or Eastin et al., 2015). This understanding was useful for describing social and technological inequalities, but it was a reductive, imprecise and inexact classification to apply in some territories with a large amount of ICT infrastructure. However, it is known that the internet and broadband penetration decreases as distance increases. So, it's still an important issue for large territories like the US, Canada or Australia, where access to reliable and fast digital connectivity is a perennial problem (Freeman et al, 2016). This gave rise to a second level of analysis of the divide based on types of use (Scheeders et al. 2017, van Deursen et al. 2015), which was in line with the EU's most recent definition, according to which the DD does not only contemplate the population that has access to the Internet and other digital technologies, but also reflects concerns about the use of commercial and government services, putting emphasis on the groups without digital access that get left behind and are missing opportunities (European Commission, 2010).

Research related to ICT applications and services has a more recent origin (Falch and Henten, 2017) and the issue has become a major policy concern. There is currently talk of a third level of analysis of the DD, which focuses on the beneficial results of Internet use (Wei et al., 2011; Van Deursen et al., 2014), making it clear that inequalities occur when, despite access to and frequent and extensive use of ICTs, 
this does not lead to beneficial socio-economic results (Van Deursen et al., 2015; Baller et al., 2016)

Even so, there is an ongoing debate on the approach to the DD which focuses exclusively on inequalities in access to the Internet (Fuchs, 2009; Selwyn, 2004; Van Dijk, 2006) especially in those territories (rural areas, less economically advanced regions, geographically isolated populations) where the limited provision of ICT infrastructure and the activities linked to them (online) will be subject to accessibility to infrastructures and the quality of internet connections (Hale et al 2010; Freeman et al, 2016). In fact, although this is not the case in all developed countries such as the US or Australia, in most european countries, a large proportion of the population has a connection to the Internet, and accordingly having a connection is no longer considered to be an element that generates digital inequality, Thus, measuring the DD on the basis of access to Internet in Europe started to be questioned when broadband and digital devices became more commonplace (Scheerder, et al., 2017) and superfast broadband began to be seen as an essential service to foster economic growth and social development (Broadband Commission, 2016). Therefore, the DD in Europe already goes beyond physical access or the economic possibility of offering a highspeed Internet connection, and is actually a complex and dynamic concept.

Thus, the European Digital Agenda 2010 focused, to a large extent, on developing ICT applications and services for citizens, which promote and facilitate their commercial, institutional and social relations. On the one hand, the Nordic countries prioritised the implementation of e-government applications, in order for citizens and businesses to request information, relate to the public authorities and apply for public services, which has led to the massive deployment of broadband (Falch and Henten, 2017). On the contrary, other countries, especially in South-Eastern Europe, have given priority to developing the broadband network prior to the diversification of applications and Internet use.

Currently, inequalities or the DD are created by the types of Internet use. Studies on Internet use have generally focused on frequency and type of activities (Purcell, 2011; Scheerder et al., 2017). Brandtzæg et al., 2011 explain the DD by identifying the variety of ways in which people in Europe use the Internet (non-users, occasional users, utility users, entertainment users and advanced users). At present, social networks have popularised Internet use by individuals seeking greater social interaction (Van Deursen et al., 2015). This trend has also increased due to the facilities provided by mobile Internet access via tablets and smartphones (Van Deursen and Van Dijk, 2013). In fact, recent research affirms that people in western countries tend to use the Internet and ICTs mainly for recreational purposes (Pearce and Rice, 2013; Van Deursen and Van Dijk, 2013; Zillien and Hargittai, 2009, Feijóo et al., 2017), and to a lesser extent for social, technical and commercial services, leisure, etc. (Kalmus et al., 2011; Amichai-Hamburger and Ben-Artzi, 2003). Hence, gaining greater knowledge of the types of use is also a means to understanding the DD, providing a more nuanced perspective on the unequal use of the Internet and participation in an increasingly digital society.

As well as the advances in the conceptualisation of the uses of ICTs and of the DD between individuals, it is also necessary to know the extent and importance of differences between countries or geographical areas (Novo-Corti and Barreiro-Gen, 2015; Schlichter and Danylchenko, 2014). Methodologies have been developed to measure the levels of access to and use of ICTs and the DD. However, the main 
indicators and indices created by different institutions to measure the DD have mainly been applied at country level: the "ICT Development Index" published by the International Telecommunication Union (ITU, 2017), the World Economic Forum's "Networked Readiness Index" (World Economic Forum, 2017) and the "Digital Economy and Society Index (DESI- European Commission, 2017), which has been published annually by the European Commission since 2014, among others. To date, these indices have been used by different studies to explain the DD in connection to socio-demographic factors and other economic characteristics of ICT users (Vehovar et al., 2006; Barzilai-Nahon, 2006; Mason and Hacker, 2003; Zoroja, 2011).

However, recent studies (Ruiz-Rodriguez et al., 2018) have shown that, to measure regional differences in access to and use of ICTs and the DD, these national indices have a number of limitations. It is worth noting, for example, a simplification of the complex interrelations between the ICT variables (Vehovar et al., 2006); the inappropriate selection of variables related to ICT technologies; or the random weight assigned to each indicator or variable in calculating the indices (OECD, 2008, Bruno et al., 2010). In this respect, European regional data (at NUTS 2 level) may be viewed via the Digital Economy and Digital Society Statistics at Regional Level (Eurostat, 2017), but the conclusions drawn refer to the variables analysed in a univariate manner, without talking into consideration the interrelationships produced between them (European Commission, 2017). Despite these limitations, the national indicators developed to measure ICT deployment and usage revealed the existence of different levels of DD between geographical areas, such as the north-south divide at global/worldwide level, or that which exists between EU Member States (Moroz, 2017; Cruz-Jesus et al., 2012; Schlichter and Danylchenko, 2014; Corrocher and Ordanini, 2002). Specifically, Billon et al. (2009 and 2016) define a spatial pattern of DD for Europe between Northern, Southern and Eastern Europe.

A line of research on the DD is accordingly opened that incorporates a new component to take into account in the analysis of the differences of level of digital development: the role of geographical space and the identification of spatial patterns of DD. The levels of technology and ICT usage of countries and geographical areas do not only depend on social, economic and governmental factors and social openness, as geographical proximity may also exert an influence on the diffusion and scale of digital development (Pick and Nishida, 2015).

With this argument, some studies have addressed the DD by using spatial analysis techniques (spatial autocorrelation) at national level in Europe (Van Dijk, 2006), the United States, Japan, China, Indonesia, etc. (Nishida et al., 2014; Pick et al., 2015; Grubesic, 2010). All of these demonstrated that geographical space is of great importance to explain the diffusion of similar ICT levels, virtual space and the DD (Grubesic and Murray, 2005; Pick et al., 2015). Hence, geographical proximity plays a relevant role in ICT usage and differences in the DD. These conclusions therefore reinforce Tobler's first law of geography (2004), which states that "everything is related to everything else, but near things are more related than distant things"; and are contrary to the theory of the death of distance (Cairncross, 1995), which defends that geographical space would cease to have importance with the development and diffusion of ICTs (Grubesic and Murray, 2005; Sujarwoto and Tampubolon, 2016). 


\section{Methodology}

\subsection{Data used: sources, variables and unit of analysis.}

The data used in this research come from the Eurostat survey "ICT usage in households and by individuals" (isoc_i) ${ }^{1}$ for 2017 . The main reason for using Eurostat statistics is that these data are available and standardised at international level, which ensures that the results of the analysis have a high degree of reliability. This survey provides data on access to and use of ICTs for two statistical units: households (all private households having at least one member in the age group 16 to 74 years); and individuals (individuals aged 16 to 74). The databases of the survey cover different areas or topics, such as "Access to IC technologies", "use of the Internet and other electronic networks for different purposes", "use of ICT by individuals to exchange information and services with governments and public administrations (egovernment)", etc.

\section{Table 1. Variables used in the analysis}

\begin{tabular}{|c|c|c|}
\hline ÁREAS & $\begin{array}{lccc}\text { VARIABLE } & \text { AND } \\
\text { MEASUREMENT } & \text { UNIT } & \text { OF } \\
\end{array}$ & ABBREVIATION \\
\hline $\begin{array}{l}\text { ACCESS TO THE } \\
\text { INTERNET AT HOME }\end{array}$ & $\begin{array}{l}\text { 1. Percentage of households with } \\
\text { access to the Internet at home } \\
\text { 2. Percentage of households with } \\
\text { broadband access } \\
\text { 3. Percentage of households with } \\
\text { broadband Internet access at } \\
\text { home }\end{array}$ & $\begin{array}{l}\text { a) H_ACCESS home } \\
\text { b) H_ACCESS broadband } \\
\text { c) H_ACCESS internet by } \\
\text { broadband }\end{array}$ \\
\hline $\begin{array}{l}\text { USE OF THE INTERNET } \\
\text { BY INDIVIDUALS }\end{array}$ & $\begin{array}{l}\text { 4. Percentage of individuals who } \\
\text { use the Internet daily } \\
\text { 5. Percentage of individuals } \\
\text { participating in social networks } \\
\text { (creating user profile, posting } \\
\text { messages or other contributions } \\
\text { to Facebook, Twitter, etc.) } \\
\text { 6. Percentage of individuals using } \\
\text { Internet banking } \\
\text { 7. Percentage of individuals selling } \\
\text { goods or services } \\
\text { 8. Percentage of individuals who } \\
\text { never use the Internet } \\
\text { 9. Percentage of individuals who } \\
\text { access the Internet away from } \\
\text { home or work }\end{array}$ & $\begin{array}{ll}\text { f) } & \text { IND_USE_banking } \\
\text { g) } & \text { IND_USE_selling } \\
\text { h) IND_USE_never } \\
\text { i) IND_ACCESS_away } \\
\text { from home or work }\end{array}$ \\
\hline $\begin{array}{l}\text { INTERACTIÓN } \text { WITH } \\
\text { PUBLIC AUTHORITIES } \\
\text { VIA E-GOVERNMENT }\end{array}$ & $\begin{array}{l}\text { 10. Percentage of individuals } \\
\text { interaction with public authorities } \\
\text { (last } 12 \text { months) } \\
\text { 11. Percentage of individuals } \\
\text { submitting completed forms (last } \\
12 \text { months) }\end{array}$ & $\begin{array}{|ll|}\text { j) } & \text { IND_INTER_public } \\
& \text { authorities } \\
& \\
\text { k) } & \text { IND_INTER_submitting } \\
& \text { forms last } 12 \mathrm{~m}\end{array}$ \\
\hline E-COMMERCE: & $\begin{array}{l}\text { 12. Percentage of individuals whose } \\
\text { last online purchase was in the } \\
\text { last } 3 \text { months } \\
\text { 13. Percentage of individuals whose } \\
\text { last online purchase was more } \\
\text { than a year ago }\end{array}$ & $\begin{array}{|ll|}\text { I) } & \text { IND_BUY_online } \\
& \text { purchase last } 3 \mathrm{~m} \\
& \\
\text { m) } & \text { IND_BUY_did not online } \\
\text { purchase in the last year }\end{array}$ \\
\hline
\end{tabular}

\footnotetext{
${ }^{1}$ http://ec.europa.eu/eurostat/web/digital-economy-and-society/data/database
} 
14. Percentage of individuals who ordered goods or services, over the Internet, for private use, more than a year ago or have never ordered

15. Percentage of individuals online purchases travel and holiday accommodation

16. Percentage of individuals online purchases from sellers from other EU countries n) IND_BUY_did not order goods or services in the last year or never

o) IND BUY purchases travel

p) IND_BUY_otherEUcoun tries

Source: own preparation.

The survey used provides data at country level for EU Member States, candidate countries, and Iceland and Norway. However, this scale often conceals intra-national differences (Corrocher and Ordanini, 2002; Pick and Nishida, 2015). In this respect, it was decided to measure the DD at regional level in this study, making use of data disaggregated by region of residence (NUTS", "isoc_reg" section), specifically, at NUTS 1 and NUTS 2 levels.

This paper studies access to and use of ICTs in households and by individuals in the regions of the 28 countries of the EU and Republic of Macedonia, Norway, Iceland, Switzerland and Turkey. The reference area chosen for the regional analysis of digital development of households and individuals in Europe is the NUTS 2 level. However, the variables of the Eurostat survey "ICT usage in households and by individuals" listed in Table 1 are disaggregated at NUTS 2 level for all the countries indicated above except for Germany, Greece, Poland, United Kingdom and Turkey. To address the lack of data at regional level for these countries and, therefore, avoid conducting an incomplete regional analysis, the NUTS 1 regions of these countries have been included in this study, for which Eurostat does offer data on the variables selected in Table 1. Consequently, in order to undertake this research, a database was developed with 16 variables of ICT usage in households and by individuals (Table 1) for 242 European regions (190 NUTS 2 and 52 NUTS $1^{3}$ ).

The exploratory data analysis (Table 2) of access to and use of ICTs in households and by individuals enables differences to be observed in the behaviour of European regions for certain variables. On the one hand, the variable $H_{-}$ACCESS internet by broadband has the highest average, with $97 \%$ of households in European regions having this type of connection. On the other hand, there is a set of variables that provide data with large standard deviations (over $16 \%$ of households and individuals), such as IND_USE_banking, IND_INTER_public authorities, IND_INTER_submitting forms last 12m, IND_BUY_online purchase last 3m, IND_BUY_purchases travel and IND_ACCESS_away from home or work. This indicates a high variability and differentiation between households and individuals in European regions for these ICTs. On the contrary, there is another set of variables with low variability (standard deviations close to $0 \%$ of households and individuals), such as the aforementioned

\footnotetext{
2 The NUTS classification (Nomenclature of territorial units for statistics) is a hierarchical system for dividing up the economic territory of the EU. Source: http://ec.europa.eu/eurostat/web/nuts. See the Appendix A.

${ }^{3}$ In the final analysis, 7 NUTS 2 and 2 NUTS 1 were omitted due to lack of data, hence in the end 233 European regions were analysed.
} 
H_ACCESS internet by broadband and IND_BUY_did not online purchase in the last year, with very similar values for households and individuals across European regions.

Furthermore, the descriptive statistical analysis showed that there are two items, IND_BUY_did not order goods or services in the last year and IND_USE_never, that behave in the opposite fashion to the other variables. Indeed, whereas European regions have low percentage values for these two variables, percentages are high for all other items, and the opposite. Thus, for the sake of statistical analyses ${ }^{4}$, the values of these variables were transformed by inverting the ranking of the same in the following manner: the percentage values of these two variables was subtracted from $100(\%)$ for each region. As a result, in the following statistical analyses, the two variables in question were changed to IND_BUY_ordered goods or services in the last year and IND_USE_ever.

Table 2. Descriptive statistics of the variables analysed.

\begin{tabular}{|l|r|r|r|r|}
\hline \multicolumn{1}{|c|}{ VARIABLES } & Mean & \multicolumn{1}{c|}{ SD } & \multicolumn{1}{c|}{ Min. } & \multicolumn{1}{c|}{ Max. } \\
\hline H_ACCESS home & 85 & 8.4 & 58 & 100 \\
\hline H_ACCESS broadband & 83 & 8.9 & 55 & 100 \\
\hline H_ACCESS internet by broadband & 97 & 3.3 & 84 & 100 \\
\hline IND_ACCESS_away from home or work & 66 & $\mathbf{1 6 . 6}$ & $\mathbf{2 6}$ & $\mathbf{9 5}$ \\
\hline IND_BUY_did not online purchase in the last year & 6 & 2.7 & 0 & 15 \\
\hline IND_BUY_online purchase last 3m & 43 & $\mathbf{1 8 . 8}$ & $\mathbf{8}$ & $\mathbf{7 5}$ \\
\hline IND_BUY_did not order goods/services in last year & 32 & 12.5 & 11 & 66 \\
\hline IND_BUY_public authorities & 22 & 12.3 & 1 & 77 \\
\hline IND_BUY_purchases travel & 30 & $\mathbf{1 7 . 9}$ & $\mathbf{1}$ & $\mathbf{6 9}$ \\
\hline IND_INTER_submitting forms last 12m & 36 & $\mathbf{1 9 . 9}$ & $\mathbf{2}$ & $\mathbf{7 7}$ \\
\hline IND_INTER_public authorities & 54 & $\mathbf{2 2 . 1}$ & $\mathbf{6}$ & $\mathbf{9 1}$ \\
\hline IND_USE_banking & 54 & $\mathbf{2 4 . 7}$ & $\mathbf{2}$ & $\mathbf{9 6}$ \\
\hline IND_USE_daily & 72 & 12.3 & 40 & 96 \\
\hline IND_USE_never & 13 & 8.8 & 0 & 35 \\
\hline IND_USE_selling & 17 & 10.1 & 1 & 44 \\
\hline IND_USE_social_networks & 56 & 12.2 & 34 & 89 \\
\hline
\end{tabular}

Source: own preparation.

\subsection{Statistical analysis.}

\subsubsection{Factor analysis.}

To study the differences in digital development between European regions, the univariate statistical analysis of the ICT variables is insufficient, as it does not enable the interrelationships that make up the underlying structure that defines digital development to be known. Measuring digital development should include the interrelationships of the multiple aspects related to the access to and use of ICTs in

\footnotetext{
${ }^{4}$ In fact, this was confirmed subsequently on performing the factor analyses, where inverse correlations were noted between these two variables and the rest. This affected the interpretation of the factors as, in the rotated component matrix, the two variables in question appeared with a minus sign, which indicated this inverse behaviour. The above-mentioned transformation of the variables did not alter either their association with their factor, or the value of the correlation coefficients with the same, it only changed their sign. Hence the new names of these two variables.
} 
households and by individuals in European regions, such as: the availability of infrastructures that enable access to the Internet; and the different types and frequency of uses of the Internet (e-commerce, public administration, social networks, etc.).

Factor analysis (FA) has been used in order to identify the interdependences between all the ICT variables. FA is a multivariate statistical technique that enables the interdependences between a broad set of variables to be analysed and identified, by aggregating them by means of common and unique factors that are not directly observable (Pérez Gil et al., 2000; Uriel, 1995; Martínez Arias, 1999). Authors such as Cruz-Jesus et al. $(2012,2016)$ or Corrocher and Ordanini (2002) consider FA to be an especially appropriate statistical technique for the analysis of digital development, given the omnipresence of ICTs in society and in the economy. In this respect, an exploratory factor analysis was performed using the main components method. The purpose of the exploratory analysis is to obtain an optimum number of factors and the factor structure underlying digital development in households and by individuals in European regions. The main components method, for its part, is the most appropriate when it is intended to initially establish a theory or model as it seeks to find the minimum number of factors that explain the largest possible amount of variance or information (Frías-Navarro and Pascual-Soler, 2012). To this end, it was decided to obtain a factor matrix rotated by the Varimax method.

\subsubsection{Construction of a synthetic index of access to and use of ICTs in households and by individuals.}

A synthetic ${ }^{5}$, objective and quantifiable index was developed to measure the average level of access to and use of ICTs in households and by individuals in each region. This index is composite as it takes into consideration the existence of the interrelationships between the variables provided by Eurostat (shown in Table 1). This index has been named the Household and Individual Digital Development Index (HIDDI) for European regions. Synthetic or complex indices allow the degree/level that these subjects reach with respect to the index developed, and to each other, to be measured and compared (Quintero, 2008). As indicated in the previous section, the use of complex indices that address the measurement of digital development and the DD of individuals and households at regional level is rare, and thus the methodology developed in a previous work was based on to develop the HIDDI (Ruiz-Rodríguez et al., 2018).

In order to develop complex indices, authors such as Poza and Fernández (2010), Castro (2009), Castaño (2011), Nunnally (1978), Stapleton (1997) and Nardo et al. (2005) recommend using multivariate statistical analysis procedures that, as well as reflecting the underlying relationships between the variables used, allow the aggregation and weighting of the same in the final index. Moreover, using these statistical methods enables some methodological problems related to the construction of the synthetic index to be addressed, namely: which aspects to be considered are relevant for adequate measurement; how to reduce the subjectivity associated with the index; how to integrate the different elements and/or criteria to be assessed; and

\footnotetext{
${ }^{5}$ In accordance with the OECD's glossary of statistical terms, we understand a synthetic index to be that mathematical combination (or aggregation) of the indicators that represent the different components of the concept to be assessed on the basis of an underlying model, providing a multidimensional assessment of the same (Saisana and Tarantola, 2002)
} 
how to evaluate or weigh the importance of these components (Barredo Cano, 1996; Corrocher and Ordanini, 2002; Galacho and Ocaña, 2006; Domínguez Serrano et al., 2011). From among the different statistical procedures for developing synthetic indices indicated by international organisations such as the OECD (2008) and the ECLAC, (developed by Schuschny and Soto, 2009), the one followed is a compensatory model (Jankowski, 1995) as the index that it is intended to develop should: i) integrate the information on all the variables relating to access to and use of ICTs in households and by individuals in European regions into one single value, paying attention to the relationships or structure underlying these data; and ii) consider the possible compensation or weighting of the criteria, that is, taking into account the weight or relative importance that each variable has in the set as a whole.

One of the most recommended multivariate statistical techniques (OECD, 2008; Schuschny and Soto, 2009) for obtaining a complex index is factor analysis (FA), as in the case of the HIDDI it is possible to know:

i) how the variables of access to and use of ICTs in households and by individuals that are going to form part of the composite indicator interrelate statistically. Indeed, the factors of the FA show the underlying or latent dimensions (not directly observable) existing between the variables based on the correlations.

ii) the weight of each variable of access to and use of ICTs according to the value of its correlation with each component (factor loading or saturation); and the relative importance of each factor or dimension within the aggregate indicator, which derives from its eigenvalue or total variance explained (Corrocher and Ordanini, 2002).

In this way, and following a bottom-up procedure, the variables on access to and use of ICTs in households and by individuals are grouped forming different factors; each factor is a dimension of the HIDDI according to its weight in the factor model; and, finally, all dimensions will be aggregated to form a single measurement, the HIDDI, of each region by calculating the weighted arithmetic mean according to the weight of each dimension (the value of the variance explained by each factor). All of this is expressed in the following equation to weight the factors by adapting the weighted linear summation (Galacho and Ocaña, 2006):

$$
H I D D I=\left(\mathrm{Afi}^{*} \mathrm{D}_{\mathrm{fi}}\right) / 100
$$

Where:

HIDDI Index of ICT Usage in Households and by Individuals

$A f_{i} \quad$ Weight of each dimension. It's the eigenvalue of each factor $(f i)$ as $\%$ of total variance explained.

$D_{f i} \quad$ Value of each Dimension or variable $(f i)$ of the $\%$ of Households and Individuals. It is calculating as the mean or average of: $C_{f i}$ (the factor loading for each variable $f i$ included in each dimension in the Table 6 Rotated component matrix); and $V_{f i}$ (the value of each ICT variable $f i$ ).

Therefore, based on this statistical procedure, the HIDDI shows the aggregate value (average) for each European region, that is, of all the variables of ICT usage analysed (Table 1). As these variables have the same unit of measurement (percentage), the HIDDI does not need standardisation and, as a result, the value of the index will be 
the average percentage of digital development of households and individuals in each European region. The proposed method makes it possible to explain the differences in levels of digital development between European regions on the basis of the factors identified. Thus, the greater the value of the HIDDI, the greater the digital development of a region, and the opposite.

The development of the HIDDI enables advances in the access to and use of ICTs in households and by individuals in different European regions to be measured jointly. The HIDDI is, therefore, a comparative measurement of digital development for all the regions of Europe. If we compare the value of the index for each European region with that which has the highest value in the HIDDI, the result shows the differences in digital development between them, that is, the DD.

\subsection{Spatial autocorrelation analysis.}

The analysis of the spatial distribution of the HIDDI makes it possible to know whether spatial patterns of digital development exist in European regions. Spatial pattern is understood to mean the way in which regions with similar values of digital development are distributed geographically. When these regions are close or adjacent they form a spatial cluster. A spatial cluster of regions implies the presence of a spatial association or autocorrelation between them. The spatial autocorrelation is based on Tobler's first law of geography (2004) which states that, in geographical space, everything is related to everything else, but near things are more related than distant things. Although it is possible to identify a spatial pattern through the cartographic representation of the HIDDI of European regions, it is essential to verify this pattern by using spatial statistical techniques. Geographical information systems (GIS) enable the analysis of spatial autocorrelation with a wide array of spatial statistical techniques.

To this end, a GIS was created with ArcGis v10.3 software by ESRI georeferencing the thematic database (prepared in this study with the 233 regions and the variables of access to and use of ICTs in households and by individuals) with vector coverage of the GISCO NUTS 2013 spatial database from Eurostat, which contains the shapefile of European NUTS. This GIS was used to examine whether there is a spatial pattern by calculating local and global indices of spatial autocorrelation since, according to Moreno and Vayá (2000), the information provided by both types of global indices is complementary. Specifically, the following analyses were performed:

a) Calculation of the global or general indices. These make it possible to confirm the existence of spatial patterns. These techniques measure, by means of calculating the indices indicated below, the degree of spatial autocorrelation, highlighting the contrasts in the geographical distribution of the regions (clustering-randomness, dependence-independence). These indices allow testing of the null hypothesis of no spatial autocorrelation, that is, of the existence of a random distribution of the variable throughout the territory.

- Moran's I index (Moran, 1948). This index is, essentially, Pearson's correlation coefficient, which maintains the range between -1 and 1 . The result of Moran's I index may be positive (the regions have values similar to their neighbours, which shows that there is a tendency of the same to cluster); negative (the opposite, very different values among neighbouring regions, indicating a dispersion of values); or without autocorrelation (the values of neighbouring regions have randomly produced values). 
- Getis-Ord General G Index (Getis and Ord, 1992) or high/low clustering tool. Having confirmed the existence of spatial autocorrelation, it measures the clustering of high or low values of the regional index. A positive $z$ score indicates that there is clustering or a concentration of high values, whereas a negative $z$ score indicates the opposite. If the $z$ score is close to zero it means that there is no clustering. The higher (or lower) the $z$ score, the greater the intensity of clustering.

b) Calculation of the local indices. These tools are based on the previous global statistics with the aim of verifying whether the structure of spatial dependence detected at global level is maintained at this level (Ramírez and Falcón, 2015). With these indicators, an index is obtained for each geographical unit analysed (regions) that shows the individual degree of dependence of each region with respect to the rest. It makes it possible to see, through the production of maps, any existing spatial clusters, that is, areas of high occurrence or spatial concentration of a phenomenon as opposed to areas of low occurrence.

- The Anselin Local Moran's I (LISA or cluster and outlier value analysis) identifies the spatial clusters or groups of regions that have similar values and spatial outlier values. This index calculates a value that represents the type of cluster for each entity: high-high $(\mathrm{HH})$, low-low (LL), high-low (HL) and low-high $(\mathrm{LH})$, as well as those not statistically significant.

- The Getis-Ord (Gi*) or optimized analysis of hot points. Getis and Ord's analysis of hot/cold spots makes it possible to see, through the production of maps, the groups or clustering of regions with high (hot spots) or low (cold spots) statistically significant values. For a region with a high/low value to be statistically significant, it must be surrounded by other entities with high/low values. Regions receive a value $( \pm 0,1,2$ and 3$)$ according to the statistical confidence level (which corresponds to reliability levels of $0 \%, 90 \%, 95 \%$ and $99 \%$, respectively), giving rise to spatial clusters.

In the calculations of these indices and maps for the analysis of the spatial autocorrelation, it is necessary to define the spatial relationships that assess each region within the context of neighbouring regions. In this study, only the European regions that are adjacent to a region are considered as its neighbours, following the "nearest neighbour rule" (“Contiguity_Edges_Only"). This threshold distance value was applied in the calculation of the indices and maps of spatial autocorrelation undertaken with the ArcGis v10.3 program, considering that the spatial relationships between European regions are defined by Euclidean distance. There are two reasons for choosing Euclidean distance: first, because the variable used to calculate the spatial autocorrelation between European regions is continuous (the value of HIDDI and of its dimensions); and, second, because the contagion effect diminishes with distance (inverse effect or impedance) as all regions affect/influence all others, but the further they are, the less the effect.

\section{Results}

\subsection{Factors that determine access to and use of ICTs in households/by individuals in European regions (FA)}


Using IMB's SPSS v23 statistical software package, a first exploratory FA was performed with the 16 variables of ICT usage in households and by individuals in European regions. The results showed that two of the original variables were not appropriate for obtaining an optimum FA. On the one hand, according to the communality values (amount of variance that each variable shares with the rest), the "IND_BUY_no online purchase in the last year" variable was not valid for the FA because it had a low value (of only 0.363 ), less than the minimum value of 0.50 , criterion established by Hair et al.. (2004) to accept a variable according to its communality. The conjunction of very little relationship with other variables (low communality) coincides with the fact that this item is also the one with the least variance (Table 3) which, overall, indicates that it must be a variable that is not sufficiently related with the resulting components, and thus it was excluded from subsequent factor analyses.

Table 3. Final Communalities.

\begin{tabular}{|l|r|r|}
\hline & Initial & Extraction \\
\hline H_ACCESS home & 1.000 & 0.844 \\
H_ACCESS internet by broadband & 1.000 & 0.851 \\
IND_USE_daily & 1.000 & 0.889 \\
IND_USE_social_networks & 1.000 & 0.622 \\
IND_USE_banking & 1.000 & 0.924 \\
IND_USE_selling & 1.000 & 0.718 \\
IND_USE_ever & 1.000 & 0.852 \\
IND_INTER_public authorities & 1.000 & 0.839 \\
IND_INTER_submitting forms last 12m & 1.000 & 0.691 \\
IND_BUY_online purchase last 3m & 1.000 & 0.878 \\
IND_BUY_ordered goods or services in the last year & 1.000 & 0.821 \\
IND_BUY_purchases travel & 1.000 & 0.890 \\
IND_BUY_public authorities & 1.000 & 0.560 \\
IND_ACCESS_away from home or work & 1.000 & 0.711 \\
IND_BUY_did not online purchase in the last year & 1.000 & 0.398 \\
\hline
\end{tabular}

Source: own preparation

On the other hand, according to the rotated component matrix of the first FA, 2 factors were obtained. All the original variables show high weights or saturations in one factor and low in the other, except the H_ACCESS broadband variable that showed high correlations with both factors. Therefore, by behaving like a complex variable, it is not appropriate to identify the nature of the factors and, consequently, it was also excluded from the model and from subsequent analyses.

After eliminating these two variables, a second FA was performed with only 14 original variables. The results of the adequacy measures (determinant, KMO test and Bartlett's sphericity test, Table 4) indicate that the variables are highly correlated with each other and, hence, the result of the FA is correct. Indeed, the determinant of the correlation matrix is very low (1.89E-012); Bartlett's test makes it possible to test the null hypothesis of absence of correlation between the variables; and the value of the KMO sampling adequacy index is equal to or more than 0.80 (specifically 0.847 ), as recommended by Kaiser (1970).

Table 4. KMO and Bartlett's test

\begin{tabular}{|l|r|}
\hline Kaiser-Meyer-Olkin sampling adequacy measure & 0.870 \\
\hline
\end{tabular}




\begin{tabular}{|l|l|r|}
\hline \multirow{2}{*}{$\begin{array}{l}\text { Bartlett's sphericity } \\
\text { test }\end{array}$} & Approximate chi-square & 6105.11 \\
\cline { 2 - 3 } & Gl & 105 \\
\cline { 2 - 3 } & Sig. & 0.000 \\
\hline
\end{tabular}

Determinant of the correlation matrix $=1.89 \mathrm{E}-012$

Source; own preparation

The choice of the final number of factors was made in accordance with total variance explained and the Kaiser method, as can be seen in Table 5. 2 factors were obtained that accumulate the largest possible amount of information (the accumulated total variance explained is almost $80 \%$, in accordance with Pearson's criterion) and moreover they are the 2 components with an eigenvalue over 1 (in accordance with Kaiser's method). Table 6 shows the factor matrix of components rotated by the Varimax method, in which the correlations between the variables and the 2 factors obtained can be seen. The interpretation of the same is as follows:

Table 5. Total variance explained

\begin{tabular}{|l|r|r|r|}
\hline \multirow{2}{*}{ Component } & \multicolumn{3}{|c|}{ Initial eigenvalues } \\
\cline { 2 - 4 } & Total & \% variance & $\begin{array}{c}\text { \% } \\
\text { accumulated }\end{array}$ \\
\hline 1 & 9.678 & 69.130 & 69.130 \\
2 & 1.438 & 10.274 & 79.404 \\
3 & 0.764 & 5.454 & 84.858 \\
4 & 0.515 & 3.682 & 88.540 \\
5 & 0.374 & 2.673 & 91.213 \\
6 & 0.360 & 2.572 & 93.785 \\
7 & 0.294 & 2.099 & 95.883 \\
8 & 0.213 & 1.524 & 97.407 \\
9 & 0.129 & 0.924 & 98.330 \\
10 & 0.078 & 0.556 & 98.886 \\
11 & 0.064 & 0.459 & 99.345 \\
12 & 0.044 & 0.312 & 99.657 \\
13 & 0.036 & 0.261 & 99.918 \\
14 & 0.011 & 0.082 & 100.000 \\
\hline
\end{tabular}

Extraction method: Principal component analysis.

Source: own preparation

Factor 1 accounts for $69.13 \%$ of the variance. It is made up of 12 variables related positively to:

i) Access to the Internet at home (H_ACCESS home).

ii) Daily use of the Internet (IND_USE_daily and IND_USE_ever).

iii) Activities carried out for particular reasons such as: online banking (IND_USE_banking), sale of goods or services (direct selling, via auctions, eBay, etc. (IND_USE_selling); online purchases in recent months, specifically some product or service (IND_BUY_online purchase last $3 \mathrm{~m}$ and IND_BUY_ordered goods or services in the last year), holiday accommodation services (hotel, apartment, etc., IND_BUY_purchases travel) or from sellers in other European Union countries (IND_BUY_otherEUcountries); contact or interaction with public administrations or services via the Internet for particular 
reasons (IND_INTER_public authorities) and/or to send completed forms (such as the income tax declaration or other taxes (IND_INTER_submitting forms last $12 \mathrm{~m})$ and,

iv) Persons who accessed the Internet away from home or work (IND_ACCESS_away from home or work).

Factor 2 only accounts for $10.27 \%$ of the variance, and establishes a relationship between two variables: use of the broadband connection to the Internet in households (H_ACCESS internet by broadband) and the use of social networks (IND_USE_social_networks).

Table 6. Rotated component matrix.

\begin{tabular}{|l|c|c|}
\hline & \multicolumn{2}{|c|}{ Component } \\
\cline { 2 - 3 } & 1 & 2 \\
\hline IND_USE_banking & 0.941 & \\
IND_BUY_online purchase last 3m & 0.918 & \\
IND_BUY_purchases travel & 0.914 & \\
IND_INTER_public authorities & 0.914 & \\
IND_BUY_ordered goods or services in the last year & 0.905 & \\
IND_USE_EVER & 0.861 & \\
IND_USE_selling & 0.847 & \\
H_ACCESS home & 0.835 & \\
IND_INTER_submitting forms last 12m & 0.831 & \\
IND_USE_daily & 0.822 & \\
IND_ACCESS_away from home or work & 0.749 & \\
IND_BUY_otherEUcountries & 0.663 & \\
\hline H_ACCESS internet by broadband & & 0.899 \\
IND_USE_social_networks & & 0.654 \\
\hline
\end{tabular}

Extraction method: Principal component analysis.

Rotation Method: Varimax with Kaiser Normalization.

\subsection{The HIDDI and its dimensions.}

The two factors extracted from the FA show the theoretical components that underlie the behaviour of access to and use of ICTs in households and by individuals in European regions. These two components of the factor model will constitute the two dimensions of the HIDDI, which will serve to develop the index itself.

Thus, Dimension 1 (DIM1), named "daily use of e-commerce, e-banking and egovernment services", is composed of factor 1 . This first component of the HIDDI means that, in European regions, access to the Internet in households and by individuals is associated with daily use of the Internet for particular reasons for ecommerce, e-banking and to relate to the public authorities via e-government whether from their own homes or away from home.

For its part, Dimension 2 (DIM2) corresponds to the "Use of social networks in households with broadband" as it is defined by the second factor that associates these two ICT variables. This component of the HIDDI shows that the use of social networks by individuals in European regions is associated with households that have broadband access to the Internet. 
As mentioned above, the HIDDI is the weighted mean of the 2 dimensions, taking into account that each has a different weight depending on the eigenvalue of its factor (Table 5). Consequently, according to the value of these weights, the equation [1] for calculating the HIDDI for European regions has the following mathematical expression:

$$
\text { HIDDI }(\%)=\left(69.48^{*} \mathrm{DIM} 1+10.34^{*} \mathrm{DIM} 2\right) / 2
$$

While the equation [2] for calculating the value of (the) DIM1 for European regions would be expressed thus:

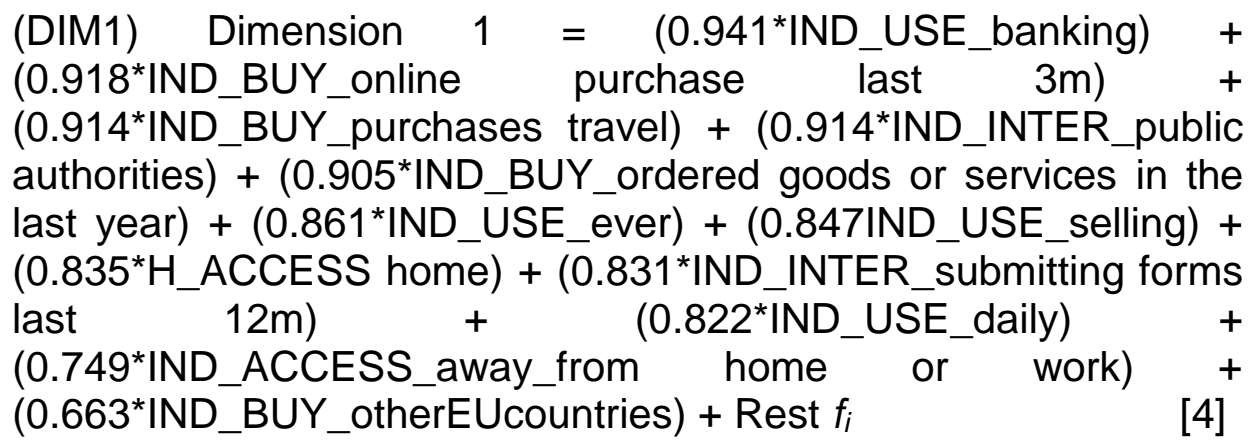

And the value of (the) DIM2 would be calculated in a similar fashion. The HIDDI of European regions is obtained with the two dimensions, and based on this a ranking of regions is made (Appendix B).

\subsection{Analysis of the spatial inequalities in digital development between European regions according to the el HIDDI.}

The statistical analysis of the HIDDI shows that on average $51.9 \%$ of households and individuals in European regions access and use ICTs. The region with the highest HIDDI in Europe is the Norwegian region of Oslo og Akershus, with $70.4 \%$ of households and individuals, while the region with the least digital development is the Romanian region of Sud-Vest Oltenia, with only $32.7 \%$ of households and individuals accessing and using ICTs. Consequently, the DD between European regions is $37.7 \%$ of households and individuals, which indicates that the most-developed region has double the percentage of households and individuals that access and use ICTs that the region with the lowest index has. Figure 1 shows the ranking of the HIDDI of European regions graphically and makes it possible to see contrasts between the same and the DD based on the calculated HIDDI.

Analysing the relationship between the index and its dimensions, two significant points can be concluded in relation to digital development and the DD (Figure 1): i) the line described by the HIDDI is very similar to that of DIM1, since the digital development of European regions is defined by DIM1; and ii) European regions behave differently according to the two dimensions of the IDHHI, which implies regional inequalities in digital development. 
Figure 1. Ranking of European regions by HIDDI and dimensions.

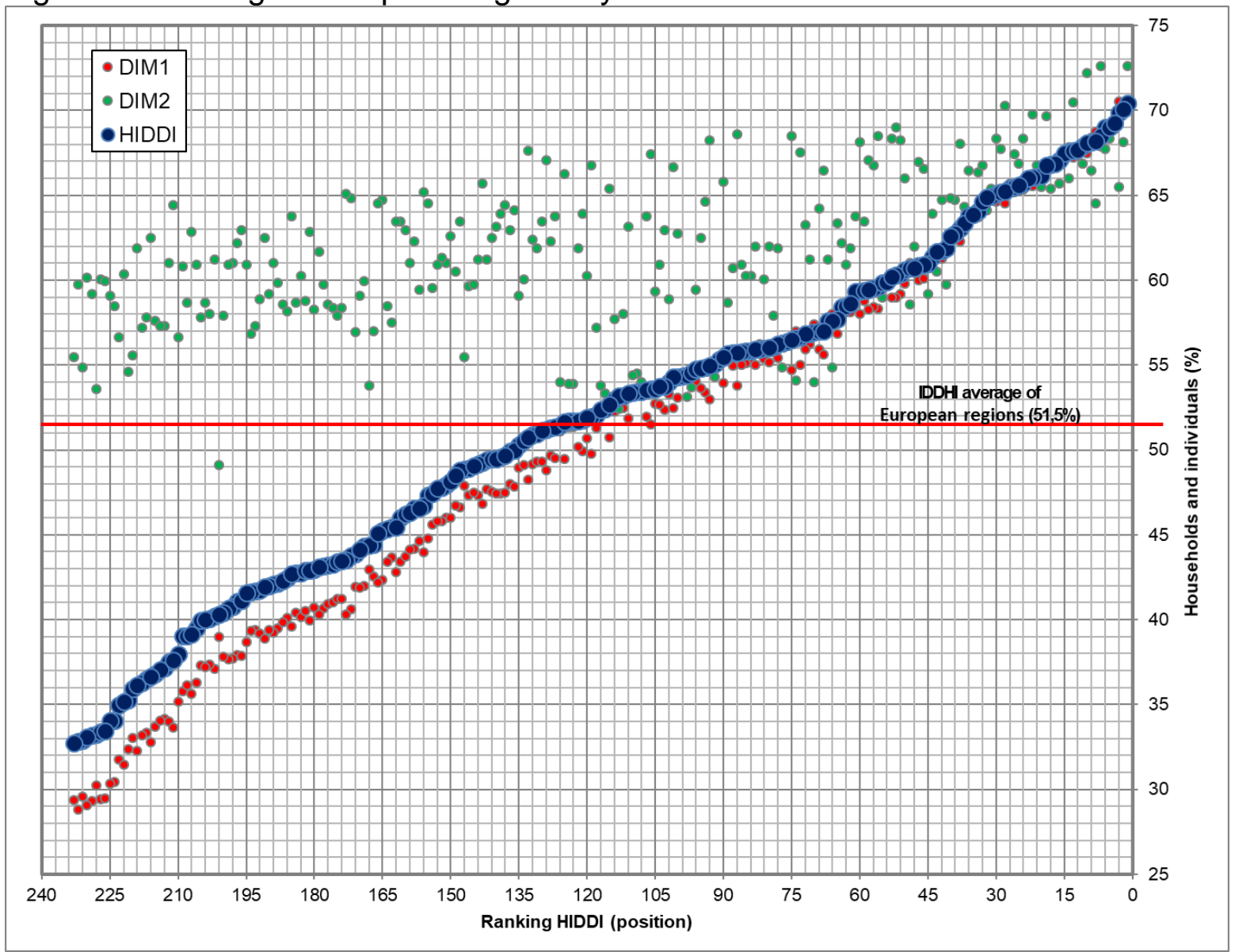

Source: own preparation

With regard to the first point, the level of digital development of European regions is fundamentally based on the daily use of ICTs for e-commerce, e-banking and egovernment (DIM1); while the use of social networks (DIM2) accounts for less in terms of the level of digital development. This is because the two dimensions have a very different weight in the final HIDDI, since this is due to the percentage of total variance explained for each of them in the factor model. If the accumulated percentage of total variance explained by the two factors is $79.8 \%$, DIM1 accounts for $87 \%$ of the HIDDI, and DIM2 accounts for the remaining $13 \%$.

On the other hand, European regions show unequal behaviour in each of the dimensions of digital development (Figure 1). Indeed, there are large contrasts between regional values in the daily use of ICTs for e-commerce, e-banking and egovernment (the coefficient of variation of DIM1 is $21.8 \%$ ). Meanwhile, the values of the use of social networks (DIM2) show very similar percentages between regions (due to a coefficient of variation of $7.2 \%$ ). This implies:

i) the use of social networks (DIM2) in European regions is more widespread than the online activities included in DIM1 (on average, $61.8 \%$ and $50.4 \%$ of households and individuals, respectively). This implies that there is a greater DD in DIM1, with a maximum difference of $41.8 \%$ of households and individuals between regions (more than double digital development between regions with the highest and lowest index). Meanwhile, DIM2 behaves in a much more egalitarian manner for European regions, with a maximum divide of $23.5 \%$ of households and individuals 
ii) there are European regions that have a higher HIDDI value than others (better position in the ranking) because they have high DIM2 values. Indeed, although the HIDDI is fundamentally determined by DIM1, as seen above, this only occurs in $60 \%$ of regions. Of these, only $12.2 \%$ are due to the regions having higher values in both dimensions; while in the rest (in $47.8 \%$ of the same), the position in the ranking is due to the fact that the DIM1 is higher. Therefore, in the remaining $40 \%$ of European regions, a region has a better position in the HIDDI ranking because it has a higher DIM2 value, even though it has a lower DIM1.

Likewise, if the spatial distribution of the HIDDI of European regions is analysed, as displayed in Fig. C.2.A , one may discern the existence of a differentiated geographical distribution of the levels of digital development in Europe. In effect, it can be seen in this map that both regions with high and those with low HIDDI values tend to be spatially concentrated, which seems to indicate the presence of spatial autocorrelation. This fact is confirmed with the result obtained with Moran's Global Index (Fig. C.1) which, first of all, rejects the null hypothesis that this spatial distribution is due to a random process ( $\mathrm{P}$ is equal to 0 ). Moreover, second, it confirms that there is an aggregate spatial distribution pattern, since Moran's index is positive (0.769). All of this shows that the distribution of the HIDDI of European regions reveals the existence of a spatial pattern of digital development in Europe at regional level. As a result, it can be affirmed that European regions with high HIDDI values have other regions with high levels of digital development as neighbours, and the opposite. For their part, the results of the Getis-Ord general index (Fig. C.1) support the existence of this spatial distribution pattern as they reject the null hypothesis that HIDDI values are randomly distributed (the $\mathrm{P}$ value is very low); and furthermore there is a cluster or concentration within the space of European regions with high HIDDI values ( $Z$ is equal to 5.045).

This pattern follows a NW-SE gradient from greater to lesser digital development in European regions and, consequently, of DD (Fig. C.2.A). Indeed, the highest levels of HIDDI are registered in the Nordic and Baltic regions along with the regions of the United Kingdom, Netherlands, Luxembourg and Switzerland (values over $57.8 \%$ of the HIDDI with access to and use of ICTs and barely $6.3 \%$ of DD). The intermediate values of digital development (between $57.8 \%$ and $46.4 \%$ ) and divide (between $12 \%$ and $23.9 \%$ ) for households and individuals are registered in the European regions located in the central European zone, from the west to the east of the continent: Spain, Ireland, France, Germany, Belgium, Austria, Slovakia, Slovenia, Latvia, Lithuania, and some western regions of Hungary. Finally, the lowest values of digital development (less than $46.4 \%$ of households/individuals) and a great DD (more than $23.9 \%$ ), are in south-east Europe, and also in regions of Portugal: Turkey, Greece, Poland, Italy, Romania, Hungary and Bulgaria (in decreasing order of HIDDI).

The local indices of the Anselin Local Moran's I (LISA) and the Getis-Ord Gi* also confirm the existence of this NW-SE spatial gradient of European regions according to the HIDDI. The LISA shows three large spatial clusters (Fig. C.2.B):

i) A High-High $(\mathrm{HH})$ group comprising regions with high HIDDI values. It groups together the NUTS with the highest levels of digital development contiguous with other regions with high values (average HIDDI of $62.7 \%$ and HIDDI values over $55 \%$ ). This group is made up of northern European regions (76 NUTS). They are the Scandinavian regions of Finland, Norway and Sweden; plus all regions of 
Denmark, Netherlands, United Kingdom and Switzerland; and some of northern Germany, Ireland and France.

ii) A Low-Low (LL) group comprising European regions with low HIDDI values. It groups the European regions with the lowest HIDDI levels (an average of $38.8 \%$ ). They are 50 NUTS from eastern and south-eastern Europe: eastern Poland, central and southern Italy and Hungary, and all of Croatia, Greece, Macedonia, Romania, Bulgaria, Cyprus and Turkey.

iii) A Low-High (LH) group that includes the regions with low-medium outlier HIDDI values. They are 4 NUTs with low HIDDI values (an average of $42.7 \%$ ) surrounded by regions with high values. Two of them are in Poland (Pólnocny and PólnocnoZachodni), one in the Czech Republic (Severozápad) and the other in Italy (Valle d'Aosta)

On the other hand, the local index of Getis-Ord $\left(\mathrm{Gi}^{*}\right)$ (Fig. C.2.C) shows 2 large groups of regions according to the HIDDI:

i) A hot spot formed by the concentration of regions with very high HIDDI values (in red on the map, with a 99\% confidence (evel). They are 26 NUTS that correspond to European regions in the north of the continent.

ii) A cold spot that groups together European regions with the lowest HIDDI values (in blue on the map at a 99\% confidence level). There are 26 NUTS in this cluster that are located in the south-east of the continent.

The clusters identified by the LISA and the $\mathrm{Gi}^{*}$ make it possible to show the DD in European regions. Thus, the regions of the $\mathrm{HH}$ and hot spot clusters (with an average HIDDI of almost $66.3 \%$ ) almost double the digital development of the regions of the LL and cold spot clusters (with an average HIDDI of only $36.2 \%$ ).

As regards the results of the analysis of the spatial distribution of the two dimensions of the HIDDI of European regions, DIM1 "Daily use of e-commerce, e-banking and egovernment" has very similar results to those of the HIDDI. This is a result of the fact that the index is determined by DIM1 since, as commented above, this dimension accounts for $87 \%$ of the HIDDI. This is corroborated by the values of the spatial autocorrelation indices (Fig.C.1) Moran's Global Index (0.339, with a Z-score of $54.4 \%$ ) and the Getis-Ord General G (with a G of 0.454 and a Z-score of $5.46 \%$ ). Similarly, the local indices of the Anselin Local Moran's I (LISA) and of the Getis-Ord $\mathrm{Gi}^{*}$ indicate a very similar spatial distribution both for the $\mathrm{HH}$ and $\mathrm{LL}$ clusters (Fig. C.3.B), and for the hot and cold spot clusters (Fig. C.3.C) of European regions in DIM1. Hence, the greatest differences in DD for households and individuals between European regions appear in relation to "Daily use of e-commerce, e-banking and egovernment".

Contrary to the HIDDI and DIM1, the analysis of the spatial distribution of DIM2, "Use of social networks by broadband", does not follow a clear NW-SE spatial gradient of digital development, its spatial distribution being more heterogeneous or, a priori, disperse (Fig. C.4.A). Thus, on the one hand, it highlights European regions with a high level of use of social networks (NUTS with more than $64 \%$ of households and individuals) that once again are basically located in the north of the continent (Norway, Finland, Denmark, Sweden, United Kingdom, Netherlands, Belgium and Luxembourg) 
along with a few disperse regions (Cyprus, almost all of Hungary and Istanbul in Turkey). On the other hand, a group of regions can be seen on the map in Fig. C.4.A with medium-high levels of use of social networks (around $60 \%$ of households and individuals) scattered throughout Europe: part of these are located in the central European corridor (Germany, Switzerland, Austria, Czech Republic, Slovakia, Hungary and Romania); others on the western (Ireland, Spain and part of Portugal) and eastern (regions of Greece, Bulgaria and Turkey) peripheries; and also in the NE of the continent (Latvia, Lithuania and Estonia). Finally, it can be observed that almost all the regions with lower levels of social network usage (under $55 \%$ of households and individuals) are located in France and central and southern Italy, as well as others in the east of Germany and Poland, Croatia and the easternmost regions of Turkey and southern Greece.

Hence, a priori, this could suggest that there is no spatial pattern of the use of social networks in European regions. This is only partly the case, according to the results of Moran's Global Index and the Getis-Ord G index (Fig.C.1). On the one hand, according to Moran's index (with a P value of 0.105 and a Z-score of 17.4) a certain degree of spatial autocorrelation exists. However, on the contrary, the Getis-Ord index has a Zscore of 0.744 , which means that the patterns of spatial association could be due to a random distribution.

The results of the local indices of spatial autocorrelation of DIM2 indicate a geographical distribution of European regions different to the NW-SE gradient of European digital development according to the HIDDI and DIM1. Thus, the map of the Anselin local Moran's I (Fig.C.4.B) reflects the fact that the cluster with the highest percentages of households and individuals that use social networks by broadband $(\mathrm{HH})$ is once again concentrated in the north of Europe $(16 \%$ of regions with an average of $67.1 \%$ of DIM2). This cluster is located in Norway and the United Kingdom (except East of England), along with a few Swedish regions (Norra Mellansverige and Västsverige) and in the centre of Belgium. Meanwhile, the cluster made up of the European regions with the lowest percentages (LL) of households and individuals that use social networks by broadband (15\% of the NUTS with a DIM2 below the average of $59.2 \%$ ) is concentrated almost exclusively in France (except the regions of Champagne-Ardenne, Nord-Pas-de-Calais, Lorraine and Corse), as well as in two regions in eastern Turkey (Ortadogu Anadolu and Kuzeydogu Anadolu).

The differing spatial behaviour of DIM2 with respect to DIM1 is also evident in the results shown by the map of the Getis-Ord-Gi* index (Fig. C.4.C). The spatial clusters signifying high percentages (hot spots with confidence levels over $90 \%$ ) of households and individuals that use social networks in Europe comprise 40 NUTS (with average DIM2 over 67\%). These regions are also located in the north of Europe, especially in Sweden, Norway, United Kingdom, Belgium, Netherlands, Denmark and Iceland. Meanwhile, the clusters of European regions with the lowest percentages of households and individuals that use social networks (cold spots with confidence levels over $99 \%$ with an average DIM2 value below $54 \%$ ) are mainly concentrated in France (except Nord-Pas-de-Calais and Lorraine). Meanwhile, the regions of central and southern Italy (and Piedmont), eastern Turkey (Ortadogu Anadolu and Kuzeydogu Anadolu), Région lémanique (Switzerland), Sachsen (Germany) and the macro-region of Pólnocno-Zachodni (Poland) form a second cold spot cluster (with a confidence level over $95 \%$ and an average DIM2 of $57 \%$ ). 
The spatial clusters identified by the LISA and the Gi* reveal that the DD between the European regions with the highest and lowest percentages of participation of individuals in social networks by broadband is small, as it does not reach 8 percentage points (an average of $67.1 \%$ in the $\mathrm{HH}$ and hot spot groups and an average of $59.2 \%$ in the LL and cold spot groups). It can therefore be affirmed that, unlike the DIM1 dimension, the values of DIM2 are more equal or similar between regions.

\section{Discussion and conclusions}

The results of this study conclude that the digital development of households and individuals in European regions is based on broadband Internet access. As pointed out above, the H_ACCESS_broadband variable is correlated with the two factors that define the dimensions of digital development ("Daily use of e-commerce, e-banking and e-government services" and "Use of social networks in households with broadband"). This confirms what other studies had already envisaged in relation to the constant evolution of the Internet and its association with broadband. This technology is necessary for most websites that contain applications requiring a high capacity for data transfer (Cruz-Jesus et al., 2016). Moreover, broadband enables individuals to be better informed online (Gijón, C., et al., 2016), benefit financially, buy and sell goods and services, and also reduce the travelling time to complete any administrative procedure, among other things (Stocker and Whalley, 2017).

Furthermore, this work provides a complex index (HIDDI) to measure the level of digital development of households and individuals in European regions and to quantify the differences or DD between them. "Unlike other indicators such as "ICT Development" of the International Telecommunications Union (ITU, 2017); "Networked Readiness Index" of the World Economic Forum (World Economic Forum, 2017); and the "Digital Economy and Society Index (DESI)" created by the European Commission to measure the Digital Society in Europe; HIDDI measures the access and use of ICTs at a subnational level (when data is available). For this reason, the HIDDI is a complementary indicator to the existing ones because it analyses the DD at a greater level of spatial detail, especially in large countries and/or countries with regional differences. In addition, the DESI is a composite index that summarises some 30 relevant indicators on Europe's digital performance and tracks the evolution of EU Member States, across five main dimensions that, unlike those of HIDDI, are not calculated with statistical criteria (Connectivity, Human Capital, Use of Internet, Integration of Digital Technology, Digital Public Services)"

It demonstrates that the level of digital development attained by European regions is due to the types of use that these make of ICTs, more specifically the daily use of ecommerce, e-banking and e-government services (DIM1). This is the differentiating factor between the level of development in European regions, and the one that establishes the levels of DD between them. This suggests that, in the context of developed economies, regional DD is associated with the more advanced uses that households and individuals make of ICTs. Consequently, this study confirms that the DD of households and individuals in European regions is "second-level" (Scheeders et al. 2017) and it is, therefore, these uses that create regional inequalities.

The values obtained by calculating the HIDDI for each European region show that the maximum DD between these is $37 \%$ of households/individuals that access and use ICTs. This confirms that, in 2017, in Europe, the DD of households and individuals already identified at country level for the 2008-10 period by Cruz-Jesus et al. (2012) 
remains the same, which implies the consolidation of spatial inequality in terms of digital development. These inequalities in the use of ICTs will continue to change over time in line with users' different needs and technological advances (Kyriakidou, et al., 2011). In Europe, households/individuals have already adopted the basic ICTs and are currently in the process of acquiring and using more advanced and productive applications that are becoming available with new ICT infrastructures (Cruz-Jesus, et al., 2016).

In this regard, studies undertaken in the USA (Howard et al., 2010; Selwyn et al., 2003), the United Kingdom, (Helsper and Galácz,2009) and the Netherlands (Van Deursen and Van Dijk, 2013; Van Deursen, et al. (2015) show that the most advanced uses of ICTs (health information, financial transactions, research, news, work, travel and product information) are used by persons with higher levels of education and employed (Van Deursen, et al., 2015). It can consequently be deduced, following Helsper (2012, Helsper, and Reisdorf, (2017).,Van Dijk (2005), Witte and Mannon (2010) and Pick and Nishida (2015), that regions and countries with a high socioeconomic level reinforce their level of digital development in comparison with regions and countries with lower levels of per capita income, thus suggesting, as a hypothesis for future studies, that the spatial distribution of digital development at regional level follows in the wake of, and is a direct result of, the socio-economic development of these geographical areas.

As mentioned above, this idea is corroborated by the existence of the NW-SE spatial pattern of digital development according to the HIDDI and DIM1 of European regions. The maps of the spatial distribution and the spatial autocorrelation indicators detected express a similar pattern to that of overall or socio-economic development. This pattern shows a gradient from greater to lesser digital development (and consequently of digital divide) which is associated with "Daily use of ICTs for e-commerce, e-banking and e-government services by households/individuals" (DIM1). Hence, this indicates that the degree of digital development and DD of European regions for households and individuals is affected by a phenomenon of dependence or spatial autocorrelation. Thus, the level of digital development of a region is directly related to that of its neighbours and, therefore, geographical proximity/vicinity is an element to take into account in the analysis of the disparities in the DD (Pick and Nishida, 2015). This is in line with Tobler's First Law of Geography (Tobler 2004) "nearby things are more similar than distant things" (Waters, 2016; Goodchild, 2018). In this respect, the three spatial clusters of European regions identified with the HIDDI follow this principle of spatial autocorrelation, as each is associated with different levels of digital development. Thus, the conglomerate of regions with the highest HIDDI is located in north-west Europe; while the cluster of regions with the lowest HIDDI values is located in the south-east of the continent; and a last set of regions with relatively intermediate HIDDI values is located in a SW-NE transcontinental strip.

However, the same does not apply to the use of social networks with broadband (DIM2). The results of this study reaffirm that the participation of individuals in social networks (creating user profiles, sending messages or other contributions to Facebook, Twitter, YouTube, etc.) is more widespread and more equal between European regions. Thus, the region with the least use of social networks has a DIM2 of almost $50 \%$ of individuals, that is, half of the population use this type of technology. While the region with the highest percentage of individuals who use social networks only exceeds that which has the least by $23 \%$ (compared with almost $42 \%$ difference in DIM1). This spread in the use of social networks in households and by individuals 
in European regions coincides with the results of different studies such as those undertaken at state level in the United States (Pick, et al., 2015) and in the prefectures of Japan (Nishida et al.. 2014). In these works, it is clear that this phenomenon may be due to the attraction that social networks have for groups of younger users/consumers; and this suggests that the use of applications is not limited to regions with a considerable deployment and use of ITCs. There are many types of social networks and they are open to all kinds of people, ages, situations and all types of use. In this respect, it has been found that in regions with a high level of access to the Internet (such as the Netherlands) the use of social networks as a means of social interaction and for games is more popular with people with lower levels of education and those with below-average income (Van Deursen, et al., 2015). Consequently, it seems to suggest that there is no limit to people's use of social networks due to age and/or level of education or income. On the contrary, in European western, the lower social classes tend to use the Internet in a more recreational and less productive manner (Hargittai and Hinnant, 2008; Livingstone and Helsper, 2007; Pearce and Rice, 2013; Van Deursen and Van Dijk, 2013; Zillien and Hargittai, 2009).

Therefore, the similar levels of individuals' use of and participation in social networks in households with broadband in European regions seem to show, according to the results obtained, a reduction in the spatial inequalities in digital development in Europe. Thus, on the one hand, the levels of spatial dependence and autocorrelation of European regions in DIM2 are less than in DIM1 (in the case of the Getis-Ord G index). And, on the other, the spatial clusters of European regions with respect to DIM2 reveal closer values of digital development and, consequently, less DD. Hence, the use of social networks by broadband has a more random distribution of spatial clusters in European regions and, therefore, a random spatial pattern. Consequently, geographical vicinity has less influence on the spatial distribution of European regions with similar levels of use of social networks by broadband. As pointed out by Shelton et al. (2015), it seems that social processes are increasingly similar from a spatial point of view due to the progressive increase in the deployment and use of ICTs, as they favour social relations regardless of the locations where these take place. Somehow or other, social networks, by going beyond borders or political boundaries, reduce space and distance and, therefore, the effect of absolute geographical proximity. As a result, according to Amin (2004), we can start to see a tenuous overlapping of the distant and the near.

The results obtained in this study are a novel contribution and increase the regional literature on the access to and use of ICTs in households and by individuals in Europe. The study contributes: 1) a methodology to measure the level of digital development and spatial inequalities that could be adopted for the analysis of different countries or geographical areas provided that they have regionalised data on ICTs; 2) a synthetic index for European regions at the level of households/individuals (HIDDI) that incorporates the multidimensionality of the phenomenon, as it has been developed on the basis of multivariate statistical methods that make it possible to: a) measure the digital development of European regions with an index adjusted to the European digital society; b) compare the level of digital development of European regions from the perspective of access to and use of ICTs in households and by individuals; $c$ ) analyse the resulting DD between European regions; and d) benefit from a dependent variable (HIDDI) obtained via statistical procedures, available for future regression models for the European regional level; and 3) a spatial pattern of digital development in European regions, analysing the weight that the phenomena of spatial dependence or autocorrelation have on a region's level of digital development. In short, the study 
highlights the importance of the proximity/vicinity of regions in the use of ICTs by households/individuals in European regions.

However, this research also has a number of limitations: 1) the number of variables included in the analysis (16) is very small. The statistical analysis of the digital development of European regions on the basis of the access and use of households/individuals would be more precise and robust (factor analysis, dimensions of the index and results of the spatial analysis) if Eurostat published more variables/indicators at NUTS 2 level; 2) Changes are produced in the statistical series on access to and use of ICTs that do not allow the use of temporal analyses. It must be borne in mind that ICTs are very dynamic technologies, and the statistics themselves need to adapt, and in fact they do, to rapid technological change. Nevertheless, it is apparent that the questionnaires include questions referring to technologies that are already obsolete or outdated in market terms; 3) there are very few conceptual models on spatial autocorrelation in digital development, and most of the research carried out is basically at country level.

Despite the limitations indicated above, the results of this research could be used for digital policy planning, and decision-making at regional level (NUTS 2). The method could also be applied (if data is available) for the geographical analysis of digital development at other spatial scales or levels. Moreover, and depending on the results obtained, future lines of research could be proposed for further or more detailed study of digital development and the DD with respect to households/individuals at regional level in Europe. For example, to determine the causes of the DD by applying spatial regression techniques that make it possible to ascertain how the spatial variable affects regional differences. This would entail closer examination not only of the impact of different elements, such as socio-economic, cultural, political and institutional aspects etc., on DD, but also of geographical variables such as the spatial proximity of regions as a mechanism for disseminating the most advanced and emerging ICTs in European regions.

\section{Acknowledgment}

This study is based on a R\&D project financed by Spanish Ministry of Economy and Competitiveness. Plan Estatal 2013-2016 Excelencia - Proyectos I+D. Ref: CSO201567662. 


\section{REFERENCES}

Alizadeh, T. (2017). Planning Deficiencies and Telecommunication Infrastructure: A Multi-level Investigation of the National Broadband Network in Australia.disP-The Planning Review, 53(3), 43-57. https://doi.org/10.1080/02513625.2017.1380411

Alizadeh, T., Farid, R. (2017). Political economy of telecommunication infrastructure: An investigation of the National Broadband Network early rollout and pork barrel politics in Australia. Telecommunications policy,41 242-252. https://doi.org/10.1016/..telpol.2017.02.002

Amichai-Hamburger, Y., Ben-Artzi, E., 2003. Loneliness and Internet use. Computers in human behavior, 19(1), 71-80. https://doi.org/10.1016/S0747-5632(02)00014-6

Amin, A., 2004. Regions unbound: towards a new politics of place. Geografiska Annaler:

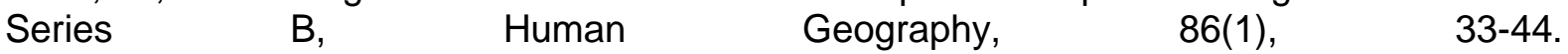
https://doi.org/10.1111/j.0435-3684.2004.00152.x

Asheim, B. T., 2018. Smart specialisation, innovation policy and regional innovation systems: what about new path development in less innovative regions? Innovation: The European Journal of Social Science Research, 1-18. https://doi.org/10.1080/13511610.2018.1491001

Baller, S., Dutta, S., Lanvin, B., 2016. Global Information Technology Report 2016. World Economic Forum and INSEAD Ouranos. http://www3.weforum.org/docs/GITR2016/WEF_GITR_Full_Report.pdf

Barredo Cano, J. I., 1996. Evaluación multicriterio y Sistemas de Información Geográfica en la Ordenación del Territorio. Madrid, Editorial RA-MA, 264.

Barzilai-Nahon, K., 2006. Gaps and bits: Conceptualizing measurements for digital divide/s. The information society, 22(5), 269-278. https://doi.org/10.1080/01972240600903953

Beugelsdijk, S., Klasing, M. J., Milionis, P., 2017. (in press) Value diversity and regional economic development. Scandinavian Journal of Economics. https://doi.org/10.1111/sjoe. 12253

Beugelsdijk, S., Klasing, M. J., Milionis, P., 2018. Regional economic development in Europe: the role of total factor productivity. Regional Studies, 52(4), 461-476. https://doi.org/10.1080/00343404.2017.1334118

Billon, M., Ezcurra, R., Lera-López, F., 2009. Spatial effects in website adoption by firms in European regions. Growth and change,40(1), 54-84. https://doi.org/10.1111/j.14682257.2008.00461.x

Billon, M., Lera-Lopez, F., Marco, R., 2016. ICT use by households and firms in the EU: links and determinants from a multivariate perspective. Review of World Economics, 152(4), 629654. https://doi.org/10.1007/s10290-016-0259-8

Brandtzæg, P. B., Heim, J., Karahasanović, A., 2011. Understanding the new digital divideA typology of Internet users in Europe. International journal of human-computer studies, 69(3), 123-138. https://doi.org/10.1016/.i.jhcs.2010.11.004

Broadband Commission, 2016. The State of Broadband: Broadband catalyzing sustainable development. Broadband Commission for Sustainable Development Available: http://broadbandcommission.org/Documents/reports/bbannualreport2016. pdf. [Accessed 05 Jan 2018].

Bruno, G., Esposito, E., Genovese, A., Gwebu, K. L., 2010. A critical analysis of current indexes for digital divide measurement. The Information Society, 27(1), 16-28 https://doi.org/10.1080/01972243.2010.534364 
Cairncross, F., 1995. The death of distance: a survey of telecommunications. The Economist 336 (7934) 5-28

Castaño, E., 2011. Multidimensional indicator for life indicators [Indicador multidimensional de indicadores de vida.] Sociology in its settings [La Sociología en sus escenarios.] pp. 5-24.

Castro, J. M., 2009. Indicators of Urban Sustainable Development. An Implementation for Andalusia. Free electronic edition. [Indicadores de Desarrollo Sostenible Urbano. Una Aplicación para Andalucía. Edición electrónica gratuita.],http://www.eumed.net/tesisdoctorales/jmc/ [Accessed 25 Feb 2018].

Charron, N., Dijkstra, L., Lapuente,V., 2015. Mapping the regional divide in Europe: A measure for assessing quality of government in 206 European regions. Social Indicators Research,122(2),315-346. https://doi.org/10.1007/s11205-014-0702-y

Corrocher, N., Ordanini, A., 2002. Measuring the digital divide: a framework for the analysis of cross-country differences, J. Inf. Technol. 17, 9-19. https://doi.org/10.1080/02683960210132061

Cruz-Jesus, F., Oliveira, T., Bacao, F., 2012. Digital divide across the European Union. Information \& Management, 49(6), 278-291. https://doi.org/10.1016/.im.2012.09.003

Cruz-Jesus, F., Vicente, M. R., Bacao, F., Oliveira, T., 2016. The education-related digital divide: An analysis for the EU-28. Computers in Human Behavior, 56, 72-82. https://doi.org/10.1016/j.chb.2015.11.027

Domínguez Serrano, M., Blancas Peral, F. J., Guerrero Casas, F. M., González Lozano, M., 2011. Una revisión crítica para la construcción de indicadores sintéticos. Revista de Métodos Cuantitativos para la Economía y la Empresa, 11.

Eastin, M. S., Cicchirillo, V., Mabry, A. 2015. Extending the digital divide conversation: Examining the knowledge gap through media expectancies. Journal of Broadcasting \& Electronic Media,59(3), 416-437. https://doi.org/10.1080/08838151.2015.1054994

European Commission, 2010. Europe 2020. A strategy for smart, suitable and inclusive growth. Brussels.

European Commission, 2017. DESI 2016. Digital economy and society index. Methodological note. Directorate-General for Communications Networks, Content and Technology, Bruxelles, Belgique. [Accessed 22 Jun 2018].

European Commision, 2019. Digital Economy and Society Index. https://digital-agendadata.eu/datasets/desi/indicators. [Accessed 1 March, 2019].

Eurostat, 2019. Regions and cities. http://ec.europa.eu/eurostat/web/nuts. [Accessed 3 March, 2019].

Eurostat, 2017. Data. https://ec.europa.eu/eurostat/web/regions/data/main-tables. [Accessed 2 Jan 2018].

Falch, M., Henten, A., 2017. Dimensions of broadband policies and developments. Telecommunications Policy. Available online 26 November 2017. https://doi.org/10.1016/j.telpol.2017.11.004

Feijóo, C., Ramos, S., Armuña, C., Arenal, A., Gómez-Barroso, J. L., 2017. A study on the deployment of high-speed broadband networks in NUTS3 regions within the framework of digital agenda for Europe. Telecommunications Policy.

https://doi.org/10.1016/j.telpol.2017.11.001

Freeman, J., Park, S., Middleton, C., \& Allen, M. (2016). The Importance of Broadband for Socio-Economic Development: A Perspective from Rural Australia. Australasian Journal of Information Systems, 20, 1-18. 
Frías-Navarro, D., Pascual-Soler, M., 2012. Exploratory factor Analysis (EFA) in consumer behavior and marketing research. Suma Psicológica,19(1), 47-58.

Fuchs, C., 2009. The role of income inequality in a multivariate cross-national analysis of the digital divide.Social Science Computer Review,27(1), 41-58. https://doi.org/10.1177/0894439308321628.

Galacho, F. B., Ocaña, C., 2006. Tratamiento con SIG y técnicas de evaluación multicriterio de la capacidad de acogida del territorio para usos urbanísticos: residenciales y comerciales. In El acceso a la información espacial y las nuevas tecnologías geográficas. Actas del XII Congreso Nacional de Tecnologías del Información Geográfica. Granada pp. 1509-1525.

Getis, A. Ord, J., 1992. The analysis of spatial association by use of distance statistics, Geographical Analysis, 24:189-206. https://doi.org/10.1111/j.1538-4632.1992.tb00261.x

Gijón, C., Whalley, J., Anderson, G., 2016. Exploring the differences in broadband access speeds across Glasgow. TelemalCTs and Informatics, 33(4), 1167-1178. https://doi.org/10.1016/j.tele.2015.11.003

Gonçalves, G., Oliveira, T., Cruz-Jesus, F., 2018. Understanding individual-level digital divide: Evidence of an African country. Computers in Human Behavior. https://doi.org/10.1016/i.chb.2018.05.039

Goodchild, M. F., 2018., A GIScience Perspective on the Uncertainty of Context. Annals of the American Association of Geographers, 1-6.

Grubesic, T. H., 2010., Efficiency in broadband service provision: A spatial $\begin{array}{llll}\text { analysis.Telecommunications } & \text { Policy, } & \text { 34(3), }\end{array}$ https://doi.org/10.1016/j.telpol.2009.11.017

Grubesic, T. H., Murray, A. T., 2005. Geographies of imperfection in telecommunication analysis. Telecommunications $\quad$ Policy, 69-94. https://doi.org/10.1016/j.telpol.2004.08.001

Hair, J.F., Anderson, R.E., Tatham, R.L., Black, W.C., 2004., Análisis Multivariante. Madrid: Pearson.

Hale, T.M., Cotton, S.R., Drentea, P. \& Goldner, M. (2010) Rural-Urban Differences in General and Health-Related Internet Use, American Behavioural Scientist, 53(9):1304- 1325.

Hargittai, E., Hinnant, A., 2008. Digital inequality: Differences in young adults' use of the Internet.Communication research,35(5),

602-621. https://doi.org/10.1177/0093650208321782

Helsper, E. J., 2012. A corresponding fields model for the links between social and digital exclusion.Communication Theory,22(4), 403-426. https://doi.org/10.1111/i.14682885.2012.01416.x

Helsper, E. J., Galácz, A., 2009. Understanding the links between social and digital exclusion in Europe. World Wide Internet: Changing Societies, Economies \& Cultures, University of Macau, Taipa, China, 146-178.

Helsper, E.J., Reisdorf, B.C., 2017. El surgimiento de una "clase inferior digital" en Gran Bretaña y Suecia: razones cambiantes para la exclusión digital. Nuevos medios y sociedad,19(8), 1253-1270.

Howard, P. N., Busch, L., Sheets, P., 2010. Comparing digital divides: Internet access and social inequality in Canada and the United States. Canadian Journal of Communication,35(1). https://doi.org/10.22230/cjc.2010v35n1a2192

lammarino, S., Rodríguez-Pose, A., Storper, M., 2018. Regional inequality in Europe: evidence, theory and policy implications. Journal of Economic Geography. https://doi.org/10.1093/jeg//by021 
INE, 2017. Encuesta sobre el uso de TIC y comercio electrónico en las empresas. Metodología, Spain, Madrid. http://www.ine.es/daco/daco42/comele/metocor.pdf. [Accessed 10 Feb 2018].

ITU-International Telecommunication Union. ICT Development Index, 2017. http://www.itu.int /net4/itu-d/idi/2017/index.html\#idi2017rank-tab, [Accessed 28 Feb, 2019].

ITU-International Telecommunication Union, 2017. Partnership core list of ICT indicators, as of March 2016. [http://www.itu.int/en/ITU/Statistics/Documents/coreindicators/Core-List-ofIndicators March2016.pdf, [Accessed 23 Jan 2018].

Jankowski, P., 1995. Integrating geographical information systems and multiple criteria decision-making methods. International Journal of Geographical Information Systems, 9, 3, pp. 251-273. https://doi.org/10.1080/02693799508902036

Jordá-Borrell, R. M., López-Otero, J., Contreras-Cabrera, G. (2018). Factors that InFluence Ict adoptlon at the country level. PLS-SEM ModellIng. Revista de economía mundial, 50, 153176.

Kalmus, V., Realo, A., Siibak, A., 2011. Motives for Internet use and their relationships with personality traits and socio-demographic factors. Trames: A Journal of the Humanities and Social Sciences, 15(4), 385.

Kraemer, K. L., Ganley, D., Dewan, S., 2005. Across the digital divide: A cross-country multitechnology analysis of the determinants of IT penetration. Journal of the Association for Information Systems,6(12), 1. https://doi.org/10.17705/1jais.00071

Kyriakidou, V., Michalakelis, C., Sphicopoulos, T., 2011. Digital divide gap convergence in Europe. Technology in Society, 33(3-4), 265-270. https://doi.org/10.1016/i.techsoc.2011.09.001

Livingstone, S., Helsper, E., 2007. Gradations in digital inclusion: Children, young people and the digital divide. New media \& society, 9 (4), 671-696 https://doi.org/10.1177/1461444807080335

Martínez Arias, M. R., 1999. El análisis multivariante en la investigación científica. Madrid: La Muralla.

Mason, S. M., Hacker, K. L., 2003. Applying communication theory to digital divide research. It \& Society, 1(5), 40-55.

Moran, P., 1948. The interpretation of statistical maps, Journal of the Royal Statistical Society $\mathrm{B}, 10: 243-251$.

Moreno, R. Vayá, E., 2000. Técnicas Econométricas para el tratamiento de datos espaciales: La econometría espacial. UB 44 manuals. Edicions Universitat de Barcelona.

Moroz, M., 2017. The Level of Development of the Digital Economy in Poland and Selected European Countries: A Comparative Analysis. Foundations of Management, 9(1), 175-190. https://doi.org/10.1515/fman-2017-0014

Nardo, M., Saisana, M., Saltelli, A., Tarantola, S., Hoffman, A.,Giovannini, E., 2005. Handbook on constructing composite indicators. France: OECD. https://doi.org/ 10.1787/533411815016, $108 \mathrm{p}$.

Nishida, T., Pick, J. B., Sarkar, A., 2014. Japan' s prefectural digital divide: A multivariate and $\begin{array}{llll}\text { spatial analysis. } & \text { Telecommunications } & \text { policy,38(11), }\end{array}$ http://dx.doi.org/10.1016/j.telpol.2014.05.004. 
Novo-Corti, I., Barreiro-Gen, M., 2015. Public policies based on social networks for the introduction of technology at home: Demographic and socioeconomic profiles of households. Computers in Human Behavior, 51, 1216-1228. https://doi.org/10.1016/i.chb.2014.12.040

Nunnally, J. 1978. Psychometric theory (p.2)

OECD-Organization for Economic Cooperation and Development-, 2001. Understanding The Digital Divide. Paris: OECD Publications. https://www.oecd.org/sti/1888451.pdf [Accessed 18 Jan 2018].

OECD-Organization for Economic Cooperation and Development (2008): Handbook on Constructing Composite Indicators: Methodology and User Guide Joint Research Center (JRC) 32 of the European Commission. Paris: OECD. https://www.oecd.org/std/42495745.pdf (Accessed 25 January 2017).

Pearce, K. E., Rice, R. E., 2013. Digital divides from access to activities: Comparing mobile and personal computer Internet users.Journal of Communication,63(4), 721-744. https://doi.org/10.1111/jcom.12045

Pérez Gil, J. A., Chacón Moscoso, S., Moreno Rodríguez, R., 2000. Validez de constructo: el uso de análisis factorial exploratorio-confirmatorio para obtener evidencias de validez. Psicothema, 12(Su2).

Pick, J. B., Nishida, T., 2015. Digital divides in the world and its regions: A spatial and multivariate analysis of technological utilization. Technological Forecasting and Social Change, 91, 1-17. https://doi.org/10.1016/j.techfore.2013.12.026

Pick, J. B., Sarkar, A., Johnson, J., 2015. United States digital divide: State level analysis of spatial clustering and multivariate determinants of ICT utilization. Socio-Economic Planning Sciences,49, 16-32. https://doi.org/10.1016/i.seps.2014.09.001

Poza, C., Fernández, J., 2010. An approach to building a multidimensional poverty indicator. Which are the risk areas in Spain? [Una aproximación a la construcción de un indicador de pobreza multidimensional. Cuáles son los focos de riesgo en España.].J. Quant. Methods Bus Econ. [Revista de métodos cuantitativos para la economía y la empresa.],10, 43-72. https://www.upo.es/revistas/index.php/RevMetCuant/article/view/2164_[Accessed 02 Mar 2018].

Purcell, K., 2011. Search and email still top the list of most popular online activities. Pew Internet \& American Life Project,9, 1-15.

Quintero, A. 2008. Guía para Diseño, Construcción e Interpretación de Indicadores. Departamento Administrativo Nacional de Estadística (DANE) Colombia.

Ramírez, L., Falcón, M., 2015. Autocorrelación espacial: analogías y diferencias entre el índice de Moran y el índice Getis y Ord. Aplicaciones con indicadores de acceso al agua en el norte argentine. Jornadas Argentinas de Geotecnologías

Riggins, F. J., Dewan, S., 2005. The digital divide: Current and future research directions. Journal of the Association for information systems, 6(12), 4.

Ruiz-Rodríguez, F., Lucendo-Monedero, A. L., González-Relaño, R., 2018. Measurement and characterisation of the Digital Divide of Spanish regions at enterprise level. A comparative analysis with the European context. Telecommunications Policy, Policy 42: 187 - 211. https://doi.org/10.1016/j.telpol.2017.11.007

Saisana, M., Tarantola, S., 2002. State-of-the-art report on current methodologies and practices for composite indicator development. European Commission, Joint Research Centre, Institute for the Protection and the Security of the Citizen, Technological and Economic Risk Management Unit. p. 214. 
Salemink, K., Strijker, D., Bosworth, G. 2017. Rural development in the digital age: A systematic literature review on unequal ICT availability, adoption, and use in rural areas. Journal of Rural Studies,54, 360-371. https://doi.org/10.1016/j.jurstud.2015.09.001

Scheerder, A., van Deursen, A., van Dijk, J. 2017. Determinants of Internet skills, uses and outcomes. A systematic review of the second-and third-level digital divide. Telematics and informatics. https://doi.org/10.1016/j.tele.2017.07.007

Schlichter, B. R., Danylchenko, L., 2014. Measuring ICT usage quality for information society building.Government Information Quarterly, 31(1), 170-184. https://doi.org/10.1016/i.giq.2013.09.003

Schuschny, A., Soto, H., 2009., Guía metodológica. Diseño de indicadores compuestos de desarrollo sostenible $\sim$ Santiago de Chile: Naciones Unidas- CEPAL.

Selwyn, N. 2004. Reconsidering political and popular understandings of the digital divide. New media \& society, 6(3), 341-362. https://doi.org/10.1177/1461444804042519

Selwyn, N., Gorard, S., Furlong, J., Madden, L. 2003. Older adults' use of information and communications technology in everyday life. Ageing \& Society, 23(5), 561-582. https://doi.org/10.1017/S0144686X03001302

Shelton, T., Poorthuis, A., Zook, M. 2015. Social media and the city: Rethinking urban sociospatial inequality using user-generated geographic information. Landscape and Urban Planning,142, 198-211. https://doi.org/10.1016/j.landurbplan.2015.02.020

Stapleton, J. 1997., DSDM, dynamic systems development method: The method in practice. Cambridge: University Press.

Stocker, V., Whalley, J., 2017. Speed isn't everything: A multi-criteria analysis of the broadband consumer experience in the UK. Telecommunications Policy 42(1), 1-14. https://doi.org/10.1016/j.telpol.2017.06.001

Sujarwoto, S., Tampubolon, G., 2016. Spatial inequality and the Internet divide in Indonesia 2010-2012.Telecommunications $\quad$ Policy, 602(7), 616. https://doi.org/10.1016/i.telpol.2015.08.008

Tobler, W., 2004. On the First Law of Geography: A Reply. Annals of the Association of American Geographers. Malden, United States: Association of American Geographers, 2004, vol. 94(2), pp. 304-310.

Uriel, E., 1995. Analisis de datos: series temporales y analisis multivariante. Editorial AC.

Van Deursen, A. J., Van Dijk, J. A., 2013. Zicht op ICT-competenties. Een werknemersperspectief in zes topsectoren. Enschede: Universiteit Twente. Consultado on line: https://ris.utwente.nl/ws/portalfiles/portal/5141963. [Accessed 28 Jan 2018].

Van Deursen, A. J., Courtois, C., Van Dijk, J. A., 2014. Internet skills, sources of support, and benefiting from Internet use. International journal of human-computer interaction, 30(4), 278290. https://doi.org/10.1080/10447318.2013.858458

Van Deursen, A. J., Van Dijk, J. A., Peter, M. 2015. Increasing inequalities in what we do online: A longitudinal cross sectional analysis of Internet activities among the Dutch population (2010 to 2013) over gender, age, education, and income. Telematics and informatics,32(2), 259-272. https://doi.org/10.1016/j.tele.2014.09.003

Van Deursen, A. J., Helsper, E. J., Eynon, R. 2016. Development and validation of the Internet Skills Scale (ISS). Information, Communication \& Society,19(6), 804-823. https://doi.org/10.1080/1369118X.2015.1078834

Van Dijk, J. A., 2005.The deepening divide: Inequality in the information society. Sage Publications. 
Van Dijk, J. A., 2006. Digital divide research, achievements and shortcomings. Poetics,34(45), 221235. https://doi.org/10.1016/i.poetic.2006.05.004

Vehovar, V., Sicherl, P., Hüsing, T., Dolnicar, V., 2006. Methodological challenges of digital divide measurements. The information society, 22(5), 279-290. https://doi.org/10.1080/01972240600904076

$\mathrm{Vu}, \mathrm{K}$. M., 2011. ICT as a source of economic growth in the information age: Empirical evidence from the 1996-2005 period.Telecommunications Policy,35(4), 357-372. https://doi.org/10.1016/i.telpol.2011.02.008

Waters, N., 2016. Tobler's First Law of Geography. International Encyclopedia of Geography: People, the Earth, Environment and Technology, 1-15.

Wei, K. K., Teo, H. H., Chan, H. C., Tan, B. C., 2011. Conceptualizing and testing a social cognitive model of the digital divide. Information Systems Research, 22(1), 170-187. https://doi.org/10.1287/isre.1090.0273

Witte, J. C., Mannon,S. E., 2010 .The internet and social inequalities.New York, NY:Routledge

World Economic Forum, 2016. Networked Readiness Index. http://reports.weforum.org /global-information-technology-report-2016/networked-readiness-index, [Accessed 18 Feb, 2019].

World Economic Forum, 2017., Shaping the Future of Digital Economy and Society. https://www.weforum.org/system-initiatives/the-digital-economy-and-society. [Accessed 12 Feb 2018].

Yu, L., 2006., Understanding Information Inequality: Making Sense of the Literature of the Information and Digital Divides. Journal of Librarianship and Information Science, 38(4), 229252. https://doi.org/10.1177/0961000606070600

Zillien, N., Hargittai, E., 2009., Digital distinction: Status-specific types of internet usage. Social Science Quarterly,90(2), 274-291. https://doi.org/10.1111/j.1540-6237.2009.00617.x

Zoroja, J., 2011., Internet, e-commerce and e-government: measuring the gap between European developed and post-communist countries. Interdisciplinary Description of Complex Systems: INDECS,9(2), 119-133. 
APPENDIX A. The NUTS classification (Nomenclature of Territorial Units for Statistics).

The European Commission and Eurostat explain because nuts classification is necessary: "National figures alone cannot reveal the full and sometimes complex picture of what is happening at a more detailed level within the European Union (EU). In this respect, statistical information at a subnational level is an important tool for highlighting specific regional and territorial aspects. It helps in analysing changing patterns and the impact that policy decisions can have on our daily life."

"The NUTS classification (Nomenclature of territorial units for statistics) is a hierarchical system for dividing up the economic territory of the EU for the purpose of:

- The collection, development and harmonisation of EU regional statistics.

- Socio-economic analyses of the regions.

- NUTS 1: major socio-economic regions.

- NUTS 2: basic regions for the application of regional policies.

- NUTS 3: small regions for specific diagnoses.

- Framing of EU regional policies.

- Regions eligible for support from cohesion policy have been defined at NUTS 2 level

- The Cohesion report has so far mainly been prepared at NUTS 2 level

Source: Eurostat (2019): http://ec.europa.eu/eurostat/web/nuts: 


\begin{tabular}{|c|c|c|c|c|c|}
\hline $\mathbf{R}$ & $\mathrm{CODE}^{\star}$ & REGION ${ }^{\star *}$ & DIM1 & DIM2 & HIDDI \\
\hline 1 & NO & Oslo og Akershus & 70.1 & 72.6 & 70.4 \\
\hline 2 & DK & Hovedstaden & 70.4 & 68.2 & 70.1 \\
\hline 3 & $\mathrm{NL}$ & Flevoland & 70.5 & 65.5 & 69.9 \\
\hline 4 & SE & Stockholm & 69.3 & 68.9 & 69.3 \\
\hline 5 & $\mathrm{FI}$ & Helsinki-Uusimaa & 69.1 & 68.4 & 69.0 \\
\hline 6 & NL & Noord-Holland & 69.2 & 67.7 & 69.0 \\
\hline 7 & IS & Ísland & 67.9 & 72.6 & 68.5 \\
\hline 8 & SE & Övre Norrland & 68.7 & 64.5 & 68.2 \\
\hline 9 & $\mathrm{NL}$ & Utrecht & 68.4 & 66.4 & 68.1 \\
\hline 10 & SE & Mellersta Norrland & 67.5 & 72.2 & 68.1 \\
\hline 11 & DK & Syddanmark & 68.0 & 66.9 & 67.9 \\
\hline 12 & DK & Midtjylland & 67.7 & 67.3 & 67.7 \\
\hline 13 & NO & Vestlandet & 67.2 & 70.5 & 67.6 \\
\hline 14 & $\mathrm{NL}$ & Groningen & 67.8 & 66.0 & 67.6 \\
\hline 15 & $\mathrm{NL}$ & Drenthe & 67.5 & 67.1 & 67.5 \\
\hline 16 & $\mathrm{NL}$ & Zeeland & 67.3 & 65.7 & 67.1 \\
\hline 17 & SE & Västsverige & 66.9 & 66.9 & 66.9 \\
\hline 18 & $\mathrm{NL}$ & Zuid-Holland & 67.0 & 65.4 & 66.8 \\
\hline 19 & NO & Nord-Norge & 66.4 & 69.6 & 66.8 \\
\hline 20 & $\mathrm{NL}$ & Noord-Brabant & 66.2 & 65.5 & 66.1 \\
\hline 21 & LU & Luxembourg & 66.0 & 66.8 & 66.1 \\
\hline 22 & NO & Agder og Rogaland & 65.5 & 69.8 & 66.1 \\
\hline 23 & SE & Sydsverige & 66.0 & 65.9 & 66.0 \\
\hline 24 & NO & Sør-Østlandet & 65.3 & 68.4 & 65.7 \\
\hline 25 & SE & Östra Mellansverige & 65.4 & 66.9 & 65.6 \\
\hline 26 & DK & Nordjylland & 65.2 & 67.4 & 65.5 \\
\hline 27 & $\mathrm{NL}$ & Limburg (NL) & 65.4 & 65.7 & 65.4 \\
\hline 28 & NO & Trøndelag & 64.5 & 70.3 & 65.3 \\
\hline 29 & NO & Hedmark og Oppland & 64.8 & 67.7 & 65.2 \\
\hline 30 & UK & London & 64.6 & 68.4 & 65.1 \\
\hline 31 & $\mathrm{NL}$ & Gelderland & 64.9 & 65.4 & 65.0 \\
\hline 32 & DK & Sjæelland & 65.0 & 64.1 & 64.9 \\
\hline 33 & $\mathrm{NL}$ & Overijssel & 64.3 & 66.8 & 64.6 \\
\hline 34 & UK & South East (UK) & 63.7 & 66.3 & 64.1 \\
\hline 35 & SE & Småland med öarna & 63.9 & 63.9 & 63.9 \\
\hline 36 & $\mathrm{NL}$ & Friesland (NL) & 63.4 & 66.4 & 63.8 \\
\hline 37 & $\mathrm{FI}$ & Etelä-Suomi & 63.2 & 64.3 & 63.4 \\
\hline 38 & UK & South West (UK) & 62.3 & 68.0 & 63.0 \\
\hline 39 & $\mathrm{FI}$ & Länsi-Suomi & 62.5 & 64.7 & 62.8 \\
\hline 40 & SE & Norra Mellansverige & 62.2 & 64.9 & 62.6 \\
\hline 41 & $\mathrm{CH}$ & Zürich & 62.2 & 59.7 & 61.9 \\
\hline 42 & $\mathrm{FI}$ & Pohjois- ja Itä-Suomi & 61.3 & 64.7 & 61.7 \\
\hline 43 & $\mathrm{CH}$ & Espace Mittelland & 61.9 & 60.5 & 61.7 \\
\hline 44 & $\mathrm{DE}$ & Hamburg & 61.0 & 63.9 & 61.4 \\
\hline 45 & $\mathrm{CH}$ & Nordwestschweiz & 61.2 & 59.2 & 60.9 \\
\hline 46 & $\mathrm{BE}$ & Prov. Vlaams-Brabant & 60.1 & 66.6 & 60.9 \\
\hline 47 & UK & West Midlands (UK) & 60.0 & 67.0 & 60.9 \\
\hline 48 & $\mathrm{CH}$ & Région lémanique & 60.5 & 62.0 & 60.7 \\
\hline 49 & FR & Île de France & 61.0 & 58.6 & 60.7 \\
\hline 50 & UK & East Midlands (UK) & 59.8 & 66.0 & 60.6 \\
\hline 51 & UK & North West (UK) & 59.2 & 68.3 & 60.4 \\
\hline 52 & UK & Scotland & 59.0 & 69.0 & 60.3 \\
\hline 53 & $\mathrm{BE}$ & Prov. Brabant Wallon & 59.0 & 68.4 & 60.2 \\
\hline 54 & $\mathrm{CH}$ & Zentralschweiz & 59.9 & 59.6 & 59.9 \\
\hline 55 & $\mathrm{CH}$ & Ostschweiz & 60.0 & 59.0 & 59.9 \\
\hline 56 & UK & Wales & 58.3 & 68.5 & 59.6 \\
\hline 57 & UK & East of England & 58.4 & 66.8 & 59.5 \\
\hline
\end{tabular}

\begin{tabular}{|c|c|c|c|c|c|}
\hline $\mathbf{R}$ & CODE & REGION & DIM1 & DIM2 & HIDDI \\
\hline 58 & $\mathrm{BE}$ & Prov. Antwerpen & 58.3 & 67.1 & 59.4 \\
\hline 59 & AT & Wien & 58.8 & 63.5 & 59.4 \\
\hline 60 & UK & Yorkshire and The Humber & 58.0 & 68.2 & 59.3 \\
\hline 61 & $\mathrm{EE}$ & Eesti & 58.7 & 63.8 & 59.3 \\
\hline 62 & UK & Northern Ireland (UK) & 58.1 & 61.9 & 58.6 \\
\hline 63 & $\mathrm{DE}$ & Berlin & 58.1 & 60.9 & 58.5 \\
\hline 64 & $\mathrm{DE}$ & Niedersachsen & 57.9 & 62.2 & 58.4 \\
\hline 65 & $\mathrm{DE}$ & Rheinland-Pfalz & 56.9 & 63.4 & 57.7 \\
\hline 66 & FR & Alsace & 58.0 & 54.8 & 57.6 \\
\hline 67 & $\mathrm{DE}$ & Hessen & 57.1 & 61.2 & 57.6 \\
\hline 68 & BE & Prov. Oost-Vlaanderen & 55.6 & 66.5 & 57.0 \\
\hline 69 & $\mathrm{IE}$ & Southern and Eastern & 55.9 & 64.2 & 57.0 \\
\hline 70 & FR & Rhône-Alpes & 57.4 & 54.0 & 57.0 \\
\hline 71 & $\mathrm{DE}$ & Nordrhein-Westfalen & 56.2 & 61.2 & 56.9 \\
\hline 72 & ES & Comunidad de Madrid & 55.9 & 63.3 & 56.9 \\
\hline 73 & UK & North East (UK) & 55.0 & 67.5 & 56.6 \\
\hline 74 & FR & Provence-Alpes-Côte d'Azur & 57.0 & 54.1 & 56.6 \\
\hline 75 & $\mathrm{BE}$ & Prov. West-Vlaanderen & 54.7 & 68.5 & 56.5 \\
\hline 76 & FR & Aquitaine & 56.4 & 56.3 & 56.4 \\
\hline 77 & FR & Midi-Pyrénées & 56.5 & 54.8 & 56.3 \\
\hline 78 & $\mathrm{CH}$ & Ticino & 55.4 & 61.9 & 56.2 \\
\hline 79 & $\mathrm{DE}$ & Bremen & 55.8 & 57.9 & 56.1 \\
\hline 80 & AT & Vorarlberg & 55.2 & 62.0 & 56.1 \\
\hline 81 & DE & Schleswig-Holstein & 55.4 & 60.1 & 56.0 \\
\hline 82 & $\mathrm{FR}$ & Bretagne & 55.9 & 56.2 & 55.9 \\
\hline 83 & AT & Tirol & 55.0 & 62.0 & 55.9 \\
\hline 84 & $\mathrm{DE}$ & Baden-Württemberg & 55.1 & 60.3 & 55.8 \\
\hline 85 & $\mathrm{DE}$ & Bayern & 55.1 & 60.3 & 55.8 \\
\hline 86 & AT & Oberösterreich & 55.0 & 60.9 & 55.8 \\
\hline 87 & $\mathrm{BE}$ & $\begin{array}{l}\text { Région de Bruxelles- } \\
\text { Capitale }\end{array}$ & 53.8 & 68.6 & 55.7 \\
\hline 88 & AT & Niederösterreich & 55.0 & 60.7 & 55.7 \\
\hline 89 & AT & Salzburg & 55.3 & 58.7 & 55.7 \\
\hline 90 & $\mathrm{BE}$ & Prov. Limburg (BE) & 53.9 & 65.8 & 55.5 \\
\hline 91 & $\mathrm{FR}$ & Bourgogne & 55.4 & 55.1 & 55.3 \\
\hline 92 & $\mathrm{FR}$ & Languedoc-Roussillon & 55.2 & 54.3 & 55.1 \\
\hline 93 & $\mathrm{BE}$ & Prov. Luxembourg (BE) & 53.0 & 68.3 & 54.9 \\
\hline 94 & ES & Illes Balears & 53.4 & 64.6 & 54.9 \\
\hline 95 & ES & $\begin{array}{l}\text { Comunidad Foral de } \\
\text { Navarra }\end{array}$ & 53.7 & 62.5 & 54.8 \\
\hline 96 & AT & Steiermark & 54.0 & 59.4 & 54.7 \\
\hline 97 & FR & Haute-Normandie & 54.7 & 53.7 & 54.6 \\
\hline 98 & FR & Pays de la Loire & 54.6 & 53.1 & 54.4 \\
\hline 99 & FR & Centre (FR) & 54.4 & 54.4 & 54.4 \\
\hline 100 & $\mathrm{DE}$ & Saarland & 53.1 & 62.7 & 54.3 \\
\hline 101 & $\mathrm{BE}$ & Prov. Namur & 52.4 & 66.7 & 54.3 \\
\hline 102 & $\mathrm{DE}$ & Sachsen & 53.3 & 58.9 & 54.0 \\
\hline 103 & $\mathrm{CZ}$ & Praha & 52.4 & 62.9 & 53.8 \\
\hline 104 & AT & Kärnten & 52.7 & 60.9 & 53.7 \\
\hline 105 & AT & Burgenland (AT) & 52.7 & 59.3 & 53.6 \\
\hline 106 & MT & Malta & 51.5 & 67.4 & 53.6 \\
\hline 107 & ES & Cataluña & 52.0 & 63.8 & 53.5 \\
\hline 108 & FR & Lorraine & 53.4 & 54.0 & 53.5 \\
\hline 109 & FR & Auvergne & 53.3 & 54.5 & 53.4 \\
\hline 110 & $\mathrm{FR}$ & Champagne-Ardenne & 53.3 & 54.4 & 53.4 \\
\hline 111 & ES & Aragón & 51.9 & 63.1 & 53.3 \\
\hline 112 & $\mathrm{DE}$ & Thüringen & 52.5 & 58.0 & 53.2 \\
\hline 113 & $\mathrm{FR}$ & Limousin & 53.3 & 52.4 & 53.2 \\
\hline 114 & DE & Sachsen-Anhalt & 52.3 & 57.7 & 53.0 \\
\hline
\end{tabular}




\begin{tabular}{|c|c|c|c|c|c|}
\hline $\mathbf{R}$ & CODE & REGION & DIM1 & DIM2 & HIDDI \\
\hline 115 & PT & $\begin{array}{l}\text { Área Metropolitana de } \\
\text { Lisboa }\end{array}$ & 50.8 & 65.4 & 52.7 \\
\hline 116 & FR & Basse-Normandie & 52.3 & 53.4 & 52.4 \\
\hline 117 & FR & Poitou-Charentes & 52.1 & 53.8 & 52.3 \\
\hline 118 & FR & Corse & 51.3 & 57.2 & 52.1 \\
\hline 119 & $\mathrm{HU}$ & Közép-Magyarország & 49.8 & 66.8 & 52.0 \\
\hline 120 & ES & País Vasco & 50.7 & 60.3 & 51.9 \\
\hline 121 & ES & $\begin{array}{l}\text { Ciudad Autónoma de } \\
\text { Ceuta }\end{array}$ & 49.9 & 63.9 & 51.7 \\
\hline 122 & ES & Cantabria & 50.2 & 61.9 & 51.7 \\
\hline 123 & FR & Nord - Pas-de-Calais & 51.4 & 53.9 & 51.7 \\
\hline 124 & FR & Franche-Comté & 51.4 & 53.9 & 51.7 \\
\hline 125 & $\mathrm{BE}$ & Prov. Liège & 49.5 & 66.2 & 51.6 \\
\hline 126 & FR & Picardie & 51.1 & 54.0 & 51.5 \\
\hline 127 & ES & Comunidad Valenciana & 49.5 & 63.8 & 51.4 \\
\hline 128 & IE & $\begin{array}{l}\text { Border, Midland and } \\
\text { Western }\end{array}$ & 49.7 & 62.3 & 51.3 \\
\hline 129 & $\mathrm{HU}$ & Közép-Dunántúl & 48.8 & 67.1 & 51.2 \\
\hline 130 & SK & Bratislavský kraj & 49.3 & 63.5 & 51.2 \\
\hline 131 & ES & Principado de Asturias & 49.3 & 61.9 & 50.9 \\
\hline 132 & ES & $\begin{array}{l}\text { Ciudad Autónoma de } \\
\text { Melilla }\end{array}$ & 49.2 & 62.4 & 50.9 \\
\hline 133 & $\mathrm{BE}$ & Prov. Hainaut & 48.3 & 67.6 & 50.8 \\
\hline 134 & $\mathrm{CZ}$ & Strední Cechy & 49.1 & 60.1 & 50.5 \\
\hline 135 & $\mathrm{DE}$ & $\begin{array}{l}\text { Mecklenburg- } \\
\text { Vorpommern }\end{array}$ & 49.0 & 59.1 & 50.3 \\
\hline 136 & ES & Andalucía & 47.8 & 64.1 & 50.0 \\
\hline 137 & LV & Latvija & 48.0 & 62.9 & 49.9 \\
\hline 138 & SK & Východné Slovensko & 47.5 & 64.4 & 49.7 \\
\hline 139 & FR & Guyane & 47.4 & 63.9 & 49.6 \\
\hline 140 & ES & Región de Murcia & 47.4 & 63.1 & 49.5 \\
\hline 141 & ES & Canarias (ES) & 47.5 & 62.5 & 49.5 \\
\hline 142 & ES & La Rioja & 47.7 & 61.2 & 49.4 \\
\hline 143 & TR & Istanbul & 46.8 & 65.7 & 49.3 \\
\hline 144 & ES & Castilla-la Mancha & 47.4 & 61.2 & 49.2 \\
\hline 145 & SI & Zahodna Slovenija & 47.5 & 59.7 & 49.1 \\
\hline 146 & ES & Castilla y León & 47.3 & 59.6 & 48.9 \\
\hline 147 & $\mathrm{DE}$ & Brandenburg & 47.9 & 55.5 & 48.9 \\
\hline 148 & ES & Extremadura & 46.6 & 63.5 & 48.8 \\
\hline 149 & SK & Stredné Slovensko & 46.7 & 60.5 & 48.5 \\
\hline 150 & SK & Západné Slovensko & 46.0 & 62.6 & 48.1 \\
\hline 151 & ES & Galicia & 46.0 & 61.0 & 47.9 \\
\hline 152 & $\mathrm{CZ}$ & Jihozápad & 45.8 & 61.3 & 47.8 \\
\hline 153 & $\mathrm{CZ}$ & Moravskoslezsko & 45.8 & 60.9 & 47.8 \\
\hline 154 & $\mathrm{CZ}$ & Jihovýchod & 45.6 & 59.5 & 47.4 \\
\hline 155 & $\mathrm{HU}$ & Nyugat-Dunántúl & 44.8 & 64.5 & 47.3 \\
\hline 156 & $\mathrm{CY}$ & Kypros & 44.0 & 65.2 & 46.7 \\
\hline 157 & SI & Vzhodna Slovenija & 44.7 & 59.4 & 46.6 \\
\hline 158 & $\mathrm{LT}$ & Lietuva & 44.2 & 62.3 & 46.5 \\
\hline 159 & $\mathrm{CZ}$ & Strední Morava & 44.1 & 61.0 & 46.3 \\
\hline 160 & EL & Attiki & 43.7 & 62.9 & 46.2 \\
\hline 161 & TR & Bati Anadolu & 43.4 & 63.5 & 46.0 \\
\hline 162 & PT & $\begin{array}{l}\text { Região Autónoma da } \\
\text { Madeira }\end{array}$ & 42.8 & 63.5 & 45.5 \\
\hline 163 & FR & Martinique & 43.7 & 57.5 & 45.5 \\
\hline 164 & $\mathrm{CZ}$ & Severovýchod & 43.4 & 58.5 & 45.4 \\
\hline 165 & $\mathrm{HU}$ & Dél-Dunántúl & 42.4 & 64.7 & 45.3 \\
\hline 166 & PT & $\begin{array}{l}\text { Região Autónoma dos } \\
\text { Açores }\end{array}$ & 42.2 & 64.5 & 45.1 \\
\hline 167 & PL & Region Centralny & 42.5 & 57.0 & 44.4 \\
\hline 168 & FR & Guadeloupe & 43.0 & 53.8 & 44.4 \\
\hline 169 & ITI & Emilia-Romagna & 42.0 & 60.0 & 44.3 \\
\hline
\end{tabular}

\begin{tabular}{|c|c|c|c|c|c|}
\hline $\mathbf{R}$ & CODE & REGION & DIM1 & DIM2 & HIDDI \\
\hline 170 & $\mathrm{CZ}$ & Severozápad & 41.9 & 59.1 & 44.1 \\
\hline 171 & ITI & $\begin{array}{l}\text { Provincia Autonoma di } \\
\text { Trento }\end{array}$ & 41.9 & 57.0 & 43.9 \\
\hline 172 & $\mathrm{HU}$ & Észak-Magyarország & 40.6 & 64.9 & 43.8 \\
\hline 173 & $\mathrm{HU}$ & Dél-Alföld & 40.3 & 65.1 & 43.5 \\
\hline 174 & ITI & Lombardia & 41.2 & 58.4 & 43.5 \\
\hline 175 & ITI & Friuli-Venezia Giulia & 41.2 & 57.9 & 43.4 \\
\hline 176 & ITI & Veneto & 41.0 & 58.4 & 43.3 \\
\hline 177 & PL & Makroregion Pólnocny & 40.9 & 58.6 & 43.2 \\
\hline 178 & PL & $\begin{array}{l}\text { Makroregion Poludniowo- } \\
\text { Zachodni }\end{array}$ & 40.7 & 59.7 & 43.2 \\
\hline 179 & PT & Centro & 40.3 & 61.7 & 43.1 \\
\hline 180 & $\mathrm{PL}$ & Makroregion Poludniowy & 40.7 & 58.3 & 43.0 \\
\hline 181 & PT & Algarve & 39.9 & 62.8 & 42.9 \\
\hline 182 & ITI & Liguria & 40.5 & 58.8 & 42.9 \\
\hline 183 & HR & Kontinentalna Hrvatska & 40.2 & 60.3 & 42.8 \\
\hline 184 & ITI & Marche & 40.4 & 58.7 & 42.8 \\
\hline 185 & $\mathrm{HU}$ & Észak-Alföld & 39.6 & 63.8 & 42.7 \\
\hline 186 & ITI & Toscana & 40.1 & 58.1 & 42.4 \\
\hline 187 & ITI & Piemonte & 39.9 & 58.6 & 42.3 \\
\hline 188 & TR & Dogu Marmara & 39.5 & 59.9 & 42.1 \\
\hline 189 & TR & Akdeniz & 39.3 & 61.0 & 42.1 \\
\hline 190 & PL & $\begin{array}{l}\text { Makroregion Pólnocno- } \\
\text { Zachodni }\end{array}$ & 39.4 & 59.2 & 42.0 \\
\hline 191 & PT & Alentejo & 38.9 & 62.5 & 41.9 \\
\hline 192 & ITI & Lazio & 39.2 & 58.9 & 41.7 \\
\hline 193 & ITI & $\begin{array}{l}\text { Provincia Autonoma di } \\
\text { Bolzano/Bozen }\end{array}$ & 39.4 & 57.3 & 41.7 \\
\hline 194 & ITI & Valle d'Aosta/Vallée d'Aoste & 39.4 & 56.9 & 41.6 \\
\hline 195 & PT & Norte & 38.7 & 60.9 & 41.6 \\
\hline 196 & RO & Bucuresti - Ilfov & 37.9 & 62.9 & 41.1 \\
\hline 197 & TR & Ege & 37.9 & 62.2 & 41.0 \\
\hline 198 & EL & Nisia Aigaiou, Kriti & 37.7 & 61.0 & 40.7 \\
\hline 199 & EL & Voreia Ellada & 37.7 & 60.9 & 40.7 \\
\hline 200 & ITI & Umbria & 37.8 & 57.9 & 40.4 \\
\hline 201 & FR & La Réunion & 39.0 & 49.1 & 40.3 \\
\hline 202 & TR & Orta Anadolu & 37.1 & 61.2 & 40.2 \\
\hline 203 & ITI & Sardegna & 37.4 & 58.0 & 40.0 \\
\hline 204 & ITI & Abruzzo & 37.2 & 58.7 & 40.0 \\
\hline 205 & $\mathrm{PL}$ & Region Wschodni & 37.3 & 57.8 & 40.0 \\
\hline 206 & TR & Bati Karadeniz & 36.3 & 60.9 & 39.5 \\
\hline 207 & $B G$ & Yugozapaden & 35.6 & 62.8 & 39.1 \\
\hline 208 & HR & Jadranska Hrvatska & 36.1 & 58.7 & 39.1 \\
\hline 209 & TR & Bati Marmara & 35.8 & 60.8 & 39.0 \\
\hline 210 & ITI & Molise & 35.2 & 56.7 & 37.9 \\
\hline 211 & RO & Vest & 33.6 & 64.4 & 37.6 \\
\hline 212 & MK & $\begin{array}{l}\text { Poranesna jugoslovenska } \\
\text { Republika Makedonija }\end{array}$ & 34.0 & 61.0 & 37.5 \\
\hline 213 & TR & Dogu Karadeniz & 34.2 & 57.3 & 37.2 \\
\hline 214 & ITI & Basilicata & 34.1 & 57.3 & 37.1 \\
\hline 215 & ITI & Sicilia & 33.7 & 57.6 & 36.8 \\
\hline 216 & RO & Nord-Vest & 32.8 & 62.5 & 36.6 \\
\hline 217 & EL & Kentriki Ellada & 33.3 & 57.8 & 36.5 \\
\hline 218 & ITI & Campania & 33.2 & 57.2 & 36.3 \\
\hline 219 & $B G$ & Severen tsentralen & 32.3 & 61.9 & 36.1 \\
\hline 220 & ITI & Puglia & 33.0 & 55.6 & 36.0 \\
\hline 221 & TR & Ortadogu Anadolu & 32.4 & 54.6 & 35.3 \\
\hline 222 & $B G$ & Severoiztochen & 31.4 & 60.4 & 35.2 \\
\hline 223 & ITI & Calabria & 31.8 & 56.7 & 35.0 \\
\hline 224 & $B G$ & Yuzhen tsentralen & 30.4 & 58.5 & 34.1 \\
\hline
\end{tabular}




\begin{tabular}{|l|l|l|r|r|r|}
\hline \multicolumn{1}{|l|}{ R } & CODE & REGION & \multicolumn{1}{c|}{ DIM1 } & \multicolumn{1}{l|}{ DIM2 } & HIDDI \\
\hline $\mathbf{2 2 5}$ & RO & Centru & 30.3 & 59.1 & $\mathbf{3 4 . 1}$ \\
\hline $\mathbf{2 2 6}$ & RO & Sud-Est & 29.5 & 60.0 & $\mathbf{3 3 . 4}$ \\
\hline $\mathbf{2 2 7}$ & BG & Yugoiztochen & 29.4 & 60.1 & $\mathbf{3 3 . 4}$ \\
\hline $\mathbf{2 2 8}$ & TR & Kuzeydogu Anadolu & 30.2 & 53.6 & $\mathbf{3 3 . 3}$ \\
\hline $\mathbf{2 2 9}$ & BG & Severozapaden & 29.3 & 59.2 & $\mathbf{3 3 . 2}$ \\
\hline $\mathbf{2 3 0}$ & RO & Sud - Muntenia & 29.1 & 60.2 & $\mathbf{3 3 . 1}$ \\
\hline $\mathbf{2 3 1}$ & TR & Güneydogu Anadolu & 29.6 & 54.8 & $\mathbf{3 2 . 9}$ \\
\hline $\mathbf{2 3 2}$ & RO & Nord-Est & 28.8 & 59.7 & $\mathbf{3 2 . 8}$ \\
\hline $\mathbf{2 3 3}$ & RO & Sud-Vest Oltenia & 29.3 & 55.5 & $\mathbf{3 2 . 7}$ \\
\hline
\end{tabular}

\begin{tabular}{ll} 
R & Number of ranking \\
${ }^{*}$ CODE & Code of Country \\
AT & Austria \\
BE & Belgium \\
BG & Bulgaria \\
CH & Switzerland \\
CY & Cyprus \\
CZ & Czech Republic \\
DE & Germany \\
DK & Denmark \\
EE & Estonia \\
EL & Greece \\
ES & Spain \\
FI & Finland \\
FR & France \\
HR & Croatia \\
HU & Hungary \\
IE & Ireland \\
IS & Iceland \\
ITI & Italy \\
LT & Latvia \\
LU & Luxembourg \\
LV & Lithuania \\
MK & Macedonia \\
MT & Malta \\
NL & Netherlands \\
NO & Norway \\
PL & Poland \\
PT & Portugal \\
RO & Romania \\
SE & Sweden \\
SI & Slovenia \\
SK & Slovakia \\
TR & Turkey \\
UK & United Kingdom \\
${ }^{*}$ REGION: NUTS & $1 / N U T S$ \\
\hline
\end{tabular}

${ }^{* *}$ REGION: NUTS 1/NUTS 2 


\section{APPENDIX C. Indices and maps of spatial autocorrelation}

Figure 1. Moran's Global Index and Getis-Ord General G Index for the HIDDI and its dimensions of European regions.

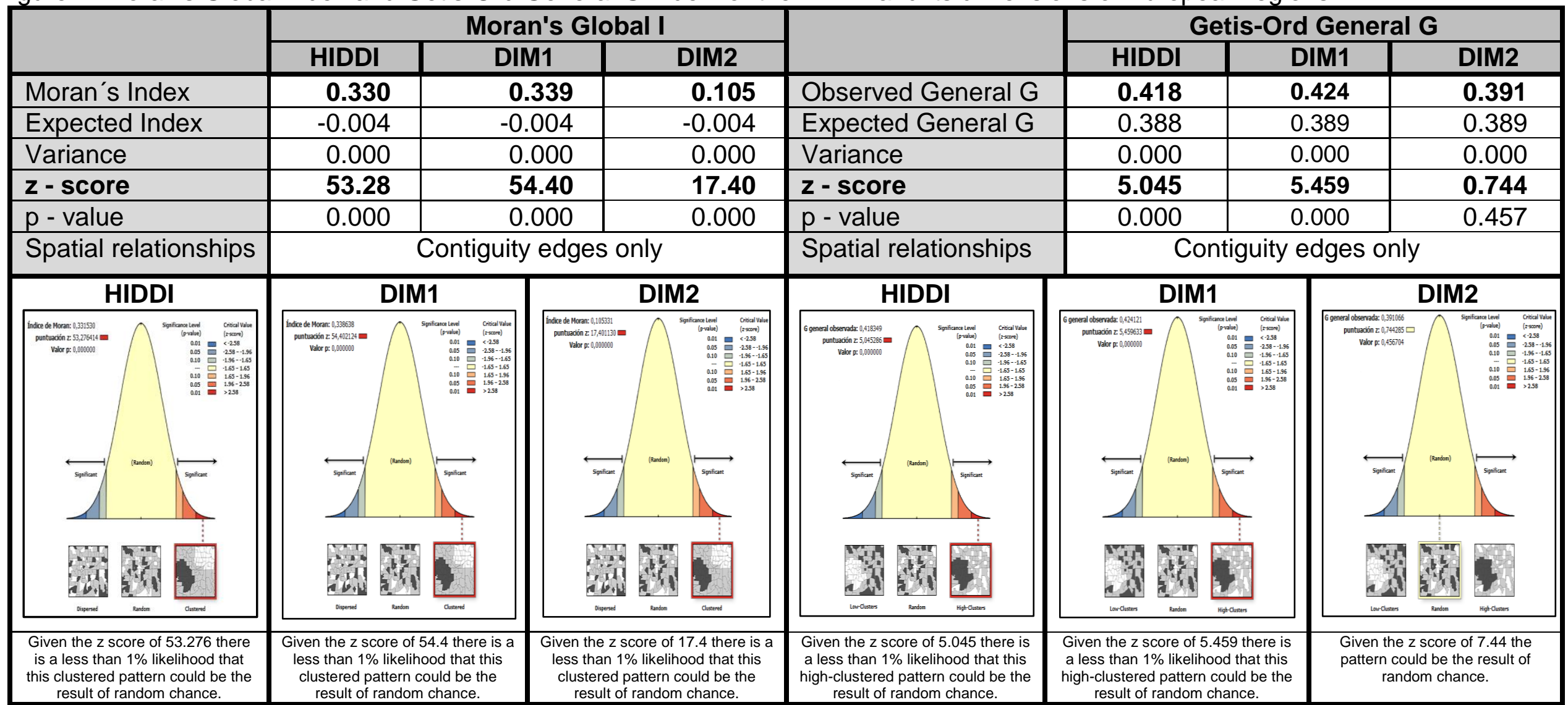

Source: Own preparation 
Figure 2. European regions according to the HIDDI (a), the Anselin Local Moran's I - LISA (b) and the Getis-Ord Gi* index (c).
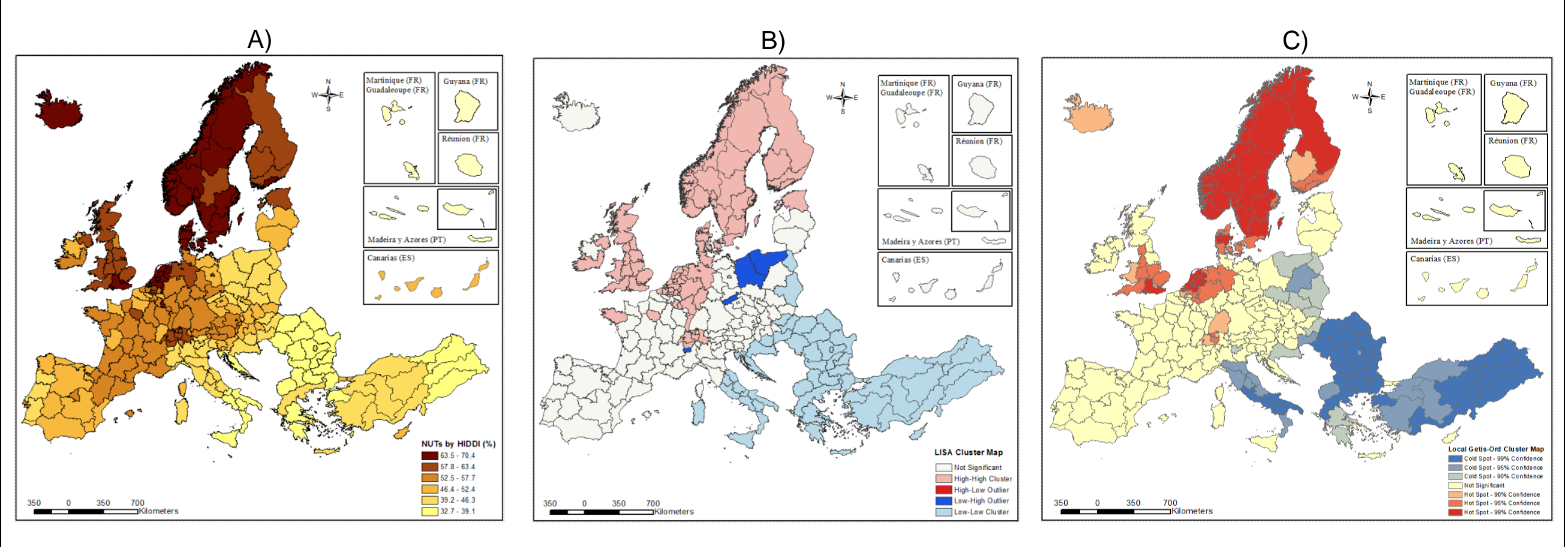

Source: Own preparation 
Figure 3. European regions according to DIM1 (a), the Anselin Local Moran's I - LISA (b) and the Getis-Ord Gi* index (c).
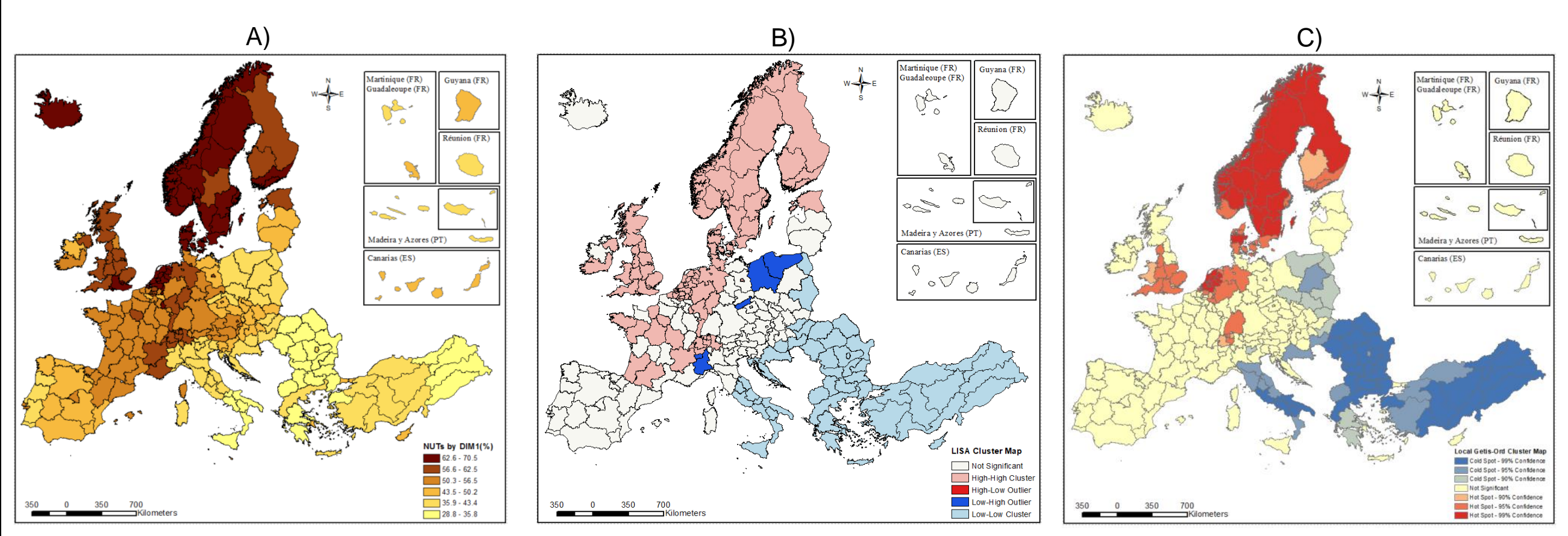

Source: Own preparation 
Figura 4. European regions regions according to DIM2 (a), the Anselin Local Moran's I - LISA (b) and the Getis-Ord Gi* index (c).

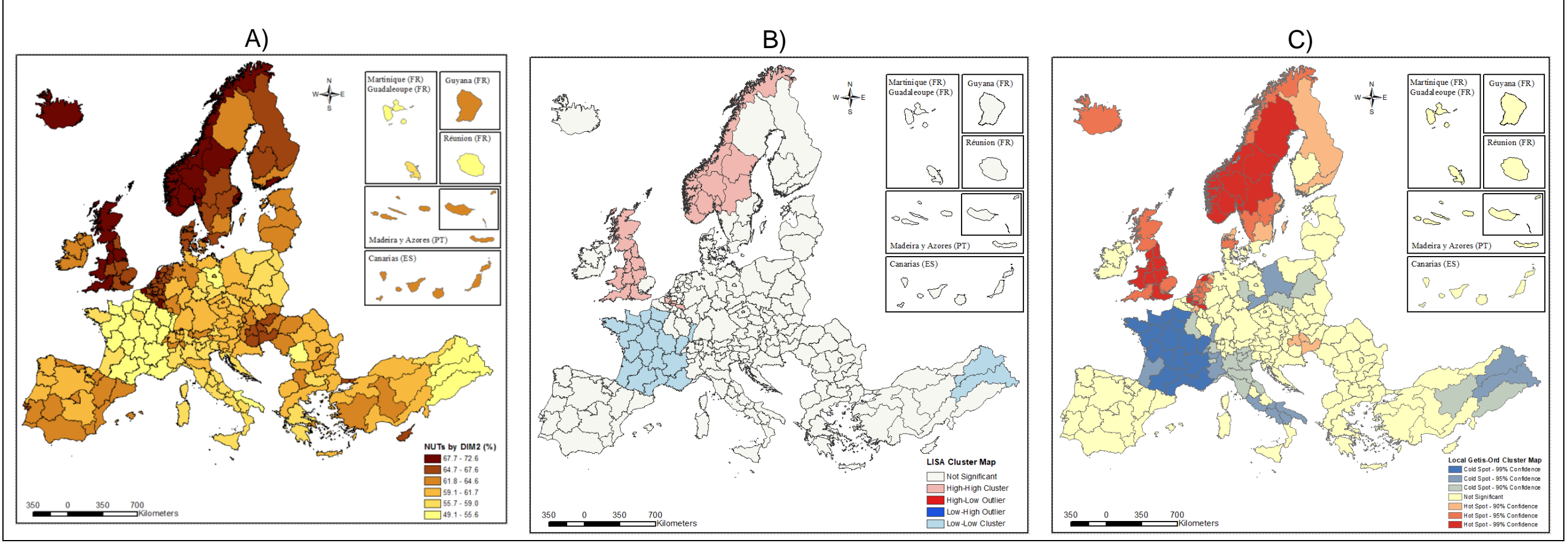

Source: Own preparation 